\title{
Knowledge coproduction improves understanding of environmental change in the Ethiopian highlands
}

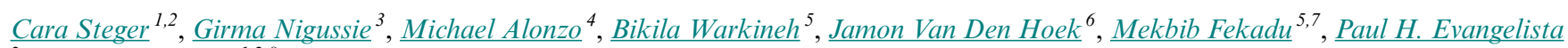 \\ ${ }^{2}$ and Julia A. Klein ${ }^{1,2,8}$
}

\begin{abstract}
Knowledge coproduction that draws on local and scientific knowledge presents opportunities for more holistic understanding of environmental change. We describe our use of a multiple-evidence based approach to investigate the causes and consequences of environmental change in a community-protected grassland and its surrounding landscape in the Ethiopian highlands. We explore the interaction of biophysical change (precipitation and vegetation) and social change (political and management institutions), and discuss potential impacts for ecosystem service provisioning. We quantified current distributions of locally defined land use/cover classes using a supervised classification, with an overall accuracy of $87.1 \%$. Local community members then described and ranked the ecosystem services associated with each land class according to their perceived importance for society. Vegetation and precipitation changes were assessed using satellite time series beginning in the early 1980s, while local narratives describe changes back to the 1970s. The knowledge coproduction process brought together ethnographic and remote sensing approaches, revealing both complementary and contradictory findings across knowledge systems. Results with high agreement across knowledge systems clarify and reinforce understanding of certain threats and changes to the area, such as the rapidly declining native forests, the disappearing belg rainy season $(\mathrm{p}=0.01)$, and the impact of insecure land tenure on natural resource extraction. Compelling areas of disagreement point to topics in need of further investigation, including increased attention to the spatial and temporal variability of change across a seemingly homogeneous cultural landscape, and the process of shrub encroachment into the protected grassland.
\end{abstract}

Key Words: ecosystem services; ethnographic methods; land use land cover change; remote sensing time series; transdisciplinary research

\section{INTRODUCTION}

Responding to changes in the structure and functioning of landscapes is a central challenge for the management of sustainable ecosystems, with far-reaching consequences for human well-being and local adaptation to global environmental change (Lambin et al. 2001, Carpenter et al. 2009, Rockström et al. 2009, DeFries et al. 2012). Biological invasions (Vitousek et al. 1996), phenological shifts (Buitenwerf et al. 2015), and unsustainable natural resource use (Persha et al. 2011) are among the most pressing drivers of change impacting ecosystems around the world. Understanding these changes within integrated socialecological systems is critical for developing effective responses, as drivers, impacts, and feedbacks among social and biophysical processes can lead to unexpected outcomes (Ostrom 2007, Turner et al. 2007, Lambin and Meyfroidt 2010).

As global environmental change continues to accelerate and intensify (Cleland et al. 2007, Steffen et al. 2011, Pepin et al. 2015), new approaches are required to build bottom-up understanding and place-based responses that connect across multiple knowledge systems and evidence streams (Tengö et al. 2014). Drawing on multiple knowledge systems, e.g., local or indigenous knowledge, different academic disciplines or work sectors, is increasingly necessary for improved understanding and management of adaptive social-ecological systems (McLain and Lee 1996, Dietz et al. 2003, Folke 2004). For example, Armitage et al. (2011) demonstrate that the combination of insights from biological science and place-based local knowledge of an Arctic fish species led to a revised understanding of the causes of fish declines and more precise management options for addressing them. The multiple benefits of these cross-knowledge collaborative approaches have been observed in other socialecological contexts, including whale conservation (Huntington 2000, Fernandez-Gimenez et al. 2006); forest change (Chalmers and Fabricius 2007); sea ice change (Nichols et al. 2004, Laidler 2006); rangeland management (Fernández-Giménez 2000, Reed et al. 2013, Klein et al. 2014, Jamsranjav et al. 2019); and fish and wildlife monitoring (Moller et al. 2004, Prado et al. 2013).

One key challenge when bringing multiple knowledge systems together is the critical need to address power dynamics. Knowledge integration has traditionally relied on scientific validation of other forms of knowledge (Agrawal 1995, Turnbull 2000), with the result that local knowledge has been overly simplified or ignored, and local communities divorced from their own knowledge and subsequent self-efficacy (Nadasdy 1999, Latulippe 2015). Knowledge coproduction differs from knowledge integration in material and philosophical ways. It is typically an iterative, ongoing collaborative process that respects and acknowledges socio-cultural contexts, resulting in a more inclusive and equitable process for generating holistic understanding about an issue (Berkes et al. 2003, Jasanoff 2004, Armitage et al. 2011, Shirk et al. 2012). A multiple evidence-based (MEB) approach (Tengö et al. 2014) is gaining attention as a

${ }^{1}$ Graduate Degree Program in Ecology, Colorado State University, Fort Collins, CO, USA, ${ }^{2}$ Natural Resource Ecology Laboratory, Colorado State University, Fort Collins, CO, USA, ${ }^{3}$ Amhara Agricultural Research Institute, Sekota Dry Land Agricultural Research Center, Ethiopia, ${ }^{4}$ Department of Environmental Science, American University, Washington, D.C., USA, ${ }^{5}$ Department of Plant Biology and Biodiversity Management, College of Natural and Computational Sciences, Addis Ababa University, Ethiopia, ${ }_{6}^{6}$ Geography Program, College of Earth, Ocean, and Atmospheric Sciences, Oregon State University, Corvallis, OR, USA., ${ }^{7}$ Department of Geography, Phillips University of Marburg, Germany, ${ }^{8}$ Department of Ecosystem Science and Sustainability, Colorado State University, Fort Collins, CO, USA 
particularly effective framework for knowledge coproduction because it emphasizes the importance of maintaining the internal validity of knowledge systems so that final products are salient, credible, and legitimate to the diverse stakeholders involved (Cash et al. 2003, Reid et al. 2006).

Community-based conservation areas present particularly valuable case studies for knowledge coproduction because there are often a mix of formal and informal institutions that support working across multiple groups of people and their respective knowledge systems (Dudley 2008, Ruiz-Mallen and Corbera 2013). When considered as a multilevel commons problem, community-based conservation areas can be simultaneously a local commons that produces ecosystem services for local consumption and well-being, and a regional commons that supports cross-scale activities like ecotourism and economic development (Berkes 2007). As such, the land tenure and management institutions that control access to these areas are often necessarily complex and highly influential on conservation outcomes (Dietz et al. 2003, Persha et al. 2011). Examining landscape-scale environmental change over time in communitybased conservation areas can enable clearer understanding of the interactions and feedbacks between biophysical and social drivers of change in these systems, and guide the development of actionable responses that are targeted to the particular strengths and vulnerabilities of that place.

Remote sensing approaches offer tools for examining the causes and consequences of environmental change at a landscape scale, and recent advances have made these tools more accessible and more appropriate for addressing different kinds of problems. Historically, the high cost of satellite imagery and lengthy processing time limited applications to using two or three images to assess change over some period of time (Coppin et al. 2002, Kennedy et al. 2014). With the full and growing global archive of NASA/USGS Landsat imagery being made freely available in 2008 (Woodcock et al. 2008), alongside the development of opensource algorithms for multidate image compositing, automated cloud-masking (Zhu and Woodcock 2012), and surface reflection correction (Masek et al. 2006), the spectral and spatial continuity between successive Landsat program satellites now more closely approximates a continuous representation of change (Wulder et al. 2019). These advancements enable a more direct engagement between remote sensing products and ethnographic narratives of change because the availability of cloud-free images no longer constrains the temporal and spatial bounds of the study.

An MEB approach, whereby people with local knowledge and knowledge derived from remote sensing are equal partners in an iterative process of knowledge coproduction, can lead to more consistent and high-quality results for both academic and nonacademic participants (Robbins and Maddock 2000, Naidoo and Hill 2006, Isager and Broge 2007, Herrmann et al. 2014). Local knowledge is increasingly viewed as necessary for remote sensing projects, particularly when validating and interpreting results (e.g., Smith et al. 2019), and is valued for its engagement at extremely fine spatial and temporal scales (Berkes 2007) and ability to address high levels of complexity and multiple variables (Berkes and Berkes 2009). Thus, the spatial breadth of remote sensing coupled with the depth of local knowledge can support detailed system understanding at a landscape scale, and the MEB process can produce culturally appropriate and actionable results for sustainable ecosystem management and adaptation to environmental change (Isager and Broge 2007).

In this study, we use an MEB approach to investigate the causes and consequences of environmental change over five political and management periods, with the aim of producing a more holistic understanding of change in a community-protected grassland and its surrounding landscape in the Ethiopian highlands. We draw on multiple knowledge systems to describe the interaction of biophysical change (precipitation and vegetation) and social change (political and management institutions), and explore potential impacts for ecosystem service provisioning. The ecosystem services concept was developed to clarify how ecosystem structures and functions work to benefit human societies (Ehrlich and Erlich 1981), and thus ecosystem services are often described as "the benefits people obtain from ecosystems" (MEA 2005:49) or conversely as "nature's benefits to people" (Díaz et al. 2015). Work on ecosystem services valuation and integration into policy is often criticized for a lack of attention to local needs, values, and knowledge (Turnhout et al. 2012, Pandeya et al. 2016). Our work, which uses the terms "ecosystem services" and "benefits" interchangeably, presents a highly local case study of integrating diverse knowledge types to better understand and manage ecosystem services.

We formalized results as maps and narratives that were edited and validated by community members, conservation managers, and local policy makers, resulting in tangible "boundary objects" for management (Star and Griesemer 1989, Steger et al. 2018). Boundary objects emerge from collaborative processes and address a societal information need, and are characterized by their interpretive flexibility and ability to apply to both specific and general contexts (Star 2010). The boundary objects produced through this research effectively combined observations and products across multiple knowledge systems to lay a foundation for future knowledge coproduction and application in this area.

\section{METHODS}

\section{Study site}

The Guassa Community Conservation Area (Guassa) is located in the Menz Gera woreda (similar to a county or district) of the Amhara Region of Ethiopia (Fig. 1). Ranging from 2600 to 3560 m.a.s.1., this area is historically characterized by two rainy seasons known as the "belg" ( 1 Feb-30 April) and "kiremt" ( 1 July-30 September). However, recent research from 2007-2012 indicates that rainfall patterns may be shifting, with more than half of the average annual $1650 \mathrm{~mm}( \pm 243 \mathrm{~mm} \mathrm{SD})$ of rainfall occurring in a unimodal peak in July and August (Fashing et al. 2014). During that same period, the average monthly temperature at Guassa was $11.0{ }^{\circ} \mathrm{C}$ ( $\pm 1.2 \mathrm{SD}$; Fashing et al. 2014). Guassa supports several endemic and threatened species, including the critically endangered Ethiopian wolf (Canis simensis) and charismatic gelada monkey (Theropithecus gelada; Ashenafi et al. 2005).

Guassa is named after the guassa grasses (Festuca spp.) that are valuable to the local communities for their use as thatch, rope, construction material, and forage. Guassa is $78 \mathrm{~km}^{2}$, and the nine communities (kebeles, the smallest administrative unit in Ethiopia) that manage and use the area occupy another $370 \mathrm{~km}^{2}$ (Fig. 1). These nine kebeles are the only communities in the region 
Fig. 1. The identifying numbers, names, population, and administrative boundaries of the nine kebeles (communities; in black) with ancestral rights to Guassa. These kebeles are all part of the Menz Gera woreda (county or district), and their numbered identifiers are used interchangeably with their local names (note: kebele 20, "Yedi", is located in two separate areas). Guassa has no human population and is administered separately as a community conservation area.

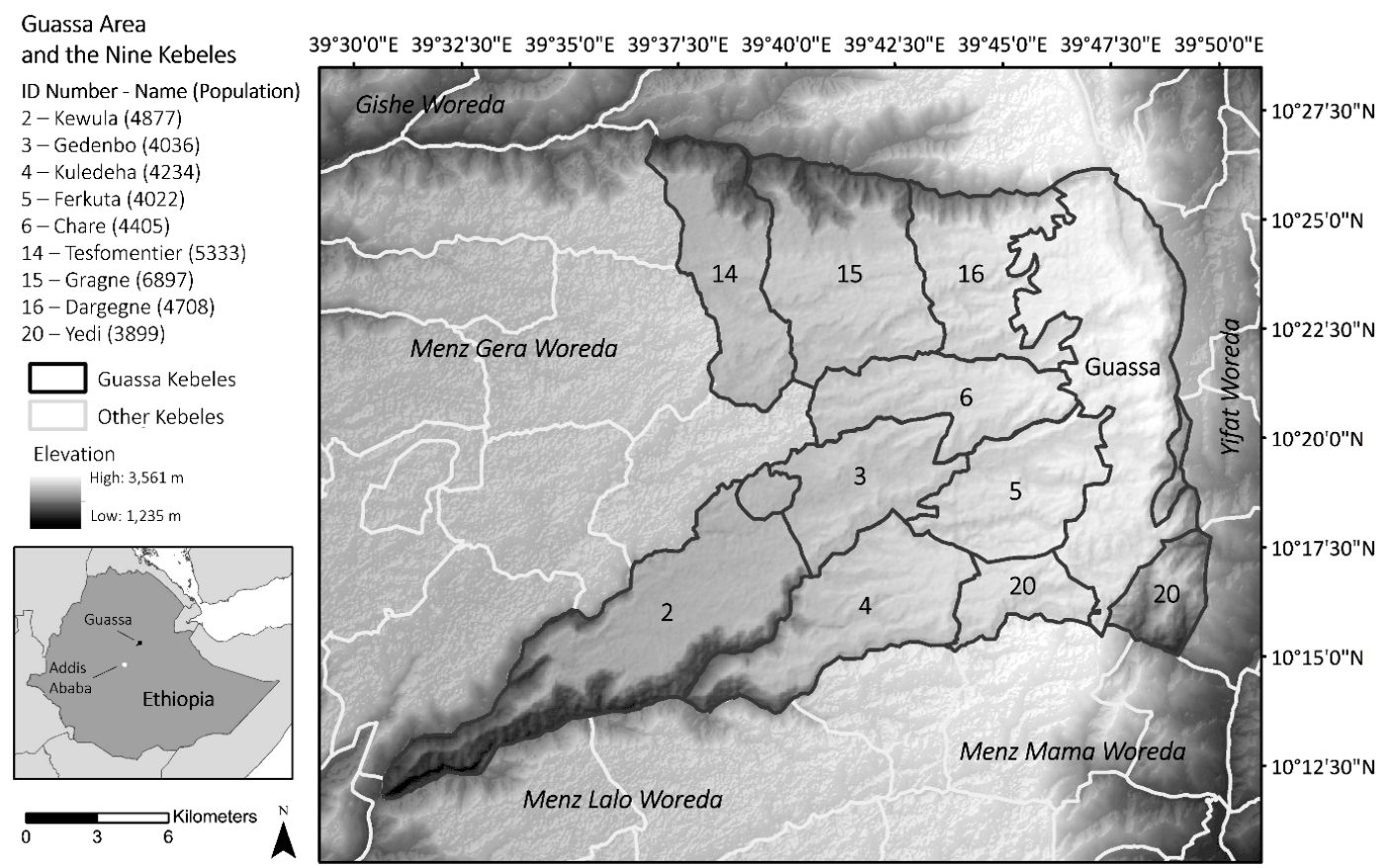

with ancestral and modern rights to Guassa, and therefore we focused our fieldwork in these areas. There are approximately 42,000 people living in these nine kebeles (CSA 2017), nearly all of whom belong to the Amhara ethnic group and the Ethiopian Orthodox Church. Increasing food insecurity in the area has resulted in roughly half the population relying on food aid programs (MGWA 2016).

Guassa has undergone significant political and land management changes throughout its history, beginning with the overthrow of the Imperial regime of Emperor Haile Selassie (pre-1974), through a period of land reform during the military regime known as the Derg (1974-1991), a transitional period of mixed government and community management (1991-2003), followed by increased NGO leadership (2003-2012), and finally the current comanagement regime (2012-present; Fig. 2). These five politicalmanagement periods were identified as key drivers of environmental change in the area during preliminary fieldwork and literature reviews (Admassie 2000, Ashenafi and LeaderWilliams 2005) and we use them to structure our subsequent analysis.

The community conservation area was managed for hundreds of years (c. 1600-1974) according to the locally unique and highly effective Qero system of communal management that restricted access to the grasses through two to three month open seasons every three to five years (Ashenafi and Leader-Williams 2005). That system was undermined when the socialist military Derg regime took over, and the 1975 agrarian reform transferred land ownership to the state, propagating decades of confusion over responsibility for Guassa's management (Admassie 2000, Ashenafi and Leader-Williams 2005). Throughout the 17-year Derg regime, the Qero system was slowly eroded in favor of de facto open access use rights, which continued into the current political regime despite community efforts to re-establish their exclusive rights (Fischer et al. 2014).

As a source of water and a refuge for wildlife, the Guassa area has been attracting increasing attention from tourists, the Ethiopian government, researchers, and international conservation organizations since about 2000 (Welch 2017). Initially, NGOs were met with skepticism from the local kebeles, but this subsided with the development of an eco-tourism project that returned profits directly to the communities. Eventually a new comanagement regime was established that restored daily management responsibilities to nine kebeles with ancestral rights to Guassa. International research interests in the area expanded to include long-term studies on the Guassa population of endemic gelada monkeys in 2006 (Fashing et al. 2014), and Ethiopian and international researchers arrive to study new aspects of the system each year. Exclusive use rights to the area were formally restored to the kebeles by Amhara Regional Regulation No. 97 in 2012. Currently the management team comprises five representatives from each of the nine kebeles (the "Guassa Committee"), of which 10 form an executive committee (the "Tourism Board"), and about 20 other individuals spread across two government offices, one administrative office at the local county (woreda) level, and the Guassa Conservation Office that is sponsored by 
Fig. 2. A timeline of political and management change in Guassa.

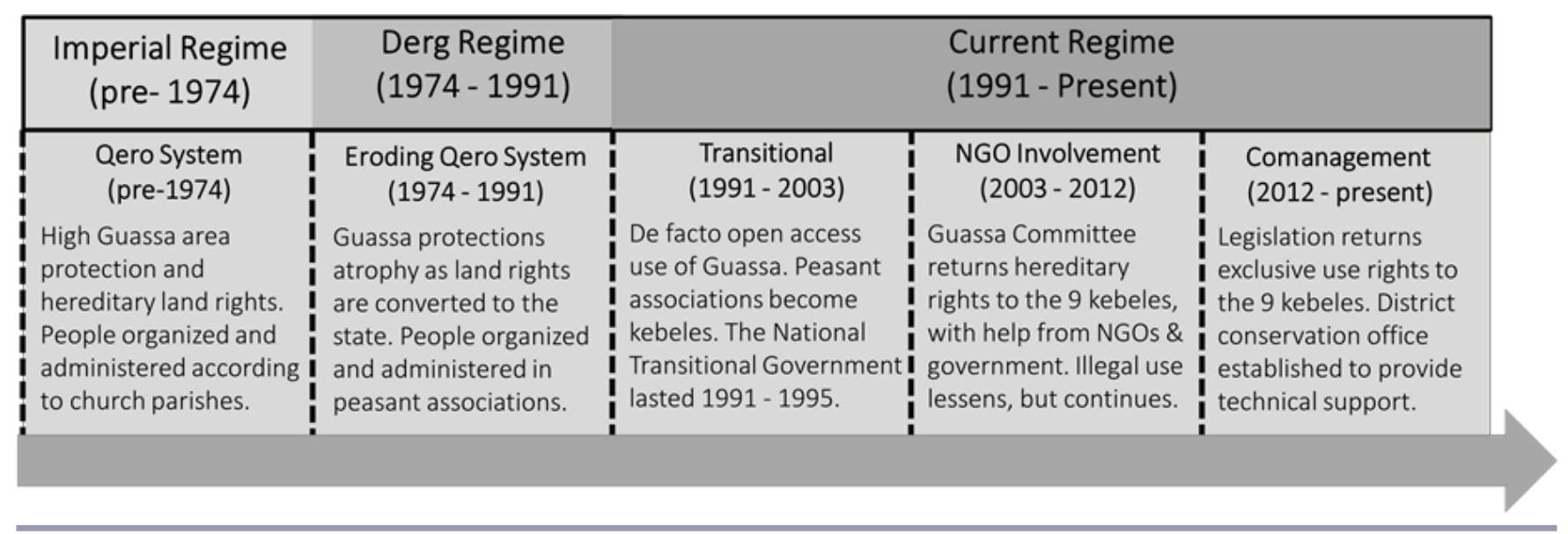

the Amhara Regional State. They manage the area collaboratively, with final decision-making power in the hands of the Guassa Committee, which meets monthly on their own and quarterly with the government offices.

\section{Data collection and analysis}

\section{Ethnographic data}

We used semistructured group interviews to identify the locally defined land classes, their associated ecosystem services, and overarching perceptions of environmental change in this area over time. Semistructured interviews are a conversational interview form that allows participants to influence the breadth and depth of topics covered (Longhurst 2003). We elected to conduct group interviews because they facilitated a rich, dynamic conversation among diverse members of a community (Gibbs 2012). Previous research has also shown that people in the Ethiopian highlands tend to state collective perceptions rather than personal experiences (Nyssen et al. 2006), which strengthened our ability to make generalizations from the relatively small number of participants. We convened a series of group interviews in March 2017 , one in each of the nine kebeles, and invited an equal number of men and women with knowledge of the conservation area to attend. We reached out to kebele administrators and asked them to identify a diverse group of people with good understanding of the Guassa area and interest in participating in a four to six hour workshop. Ten men and 10 women attended the first interview, and we determined that was too many for a productive conversation. We limited the remaining interviews to 10 to 12 people for a total of 106 participants across nine kebeles, with equal gender representation. The average age of participants was 42 years old, ranging from 18 to 88 years.

In each group interview, we requested that participants discuss and describe the categories they use to think about and organize their land, both in the kebele lands and in the Guassa area. After establishing this list of land classes, we then asked how those land classes have been changing over the five political-management periods of Guassa. For each land class, we requested that the group free list all the ecosystem services (translated as "benefits") they receive from that land class, and a research assistant wrote them on a chalkboard. We then collectively grouped the ecosystem services into a smaller set of distinct services, e.g., "making tools" and "making bowls" were determined to be essentially the same service of "household items." As a group, participants ranked the services in each land class to identify which were most important to their community. This entailed group discussions and voting to achieve consensus, which took no longer than two hours. Throughout the discussions, we facilitated participation to prevent certain individuals or groups from dominating the conversation. Finally, participants were supplied with markers, blank paper, and high-resolution Google Earth images of their kebele and asked to identify the general distribution of these land classes following a standard "participatory mapping" protocol (Klain and Chan 2012, Luizza et al. 2016, Wakie et al. 2016). An example of the kebele-level maps produced is given in Appendix 1 (Fig. A1.1). This research was reviewed and approved by Colorado State University's Institutional Review Board (361-18H), and was conducted with free, prior, and informed consent of all participants. All participants were offered modest financial compensation for their time.

We used the software package ANTHROPAC (Borgatti 1996) to analyze the ecosystem service data and calculate the relative importance of each service across the nine kebeles based on their ranked positions. The software calculates Smith's salience value (S) from zero to one for each item in a list, considering both the frequency of the item across lists and its position within each of those lists (Borgatti 1996, Levine et al. 2017). Salience values closer to one indicate good agreement across the nine kebeles regarding the importance of a particular ecosystem service.

\section{Remote sensing and precipitation data}

Following the group interviews, we conducted a supervised classification of Landsat 8 optical imagery using a random forest classifier implemented in the randomForest package in $\mathrm{R}$ (Breiman 2001, R Core Development Team 2019). Random forest is a machine learning technique that uses bagging, i.e., random resampling with replacement, to average across large numbers of decision trees and thus produces more accurate classifications than single trees alone (Breiman 2001, Rodriguez-Galiano et al. 2012). A random forest classifier provides flexibility by allowing for nonlinear relationships between predictor and response 
Table 1. Description of 27 predictor variables used in the supervised classification.

\begin{tabular}{|c|c|}
\hline Variable & Description \\
\hline aspect & downslope direction \\
\hline elevation & meters above sea level \\
\hline slope & degree of tilt \\
\hline Band 1 & Landsat 8 OLI coastal aerosol band \\
\hline Band 2 & Landsat 8 OLI blue band \\
\hline Band 3 & Landsat 8 OLI green band \\
\hline Band 4 & Landsat 8 OLI red band \\
\hline Band 5 & Landsat 8 OLI near infrared band \\
\hline Band 6 & Landsat 8 OLI short-wave infrared band 1 \\
\hline Band 7 & Landsat 8 OLI short-wave infrared band 2 \\
\hline wetness & weighted linear combination of Landsat 8 OLI bands to produce a measure of soil or surface moisture \\
\hline greenness & $\begin{array}{l}\text { weighted linear combination of Landsat } 8 \text { OLI bands to produce a measure of photosynthetically active } \\
\text { vegetation }\end{array}$ \\
\hline brightness & $\begin{array}{l}\text { weighted linear combination of Landsat } 8 \text { OLI bands to produce an albedo-like measure of surface } \\
\text { reflectance }\end{array}$ \\
\hline CoMgmt_DOY253 & Spline interpolated NBR values during the Comanagement period for the wet season (10 September) \\
\hline CoMgmt_DOY40 & Spline interpolated NBR values during the Comanagement period for the dry season (9 February) \\
\hline CoMgmt_NGO_DOY253 & $\begin{array}{l}\text { Difference of spline interpolated NBR values between the Comanagement and NGO periods for the wet } \\
\text { season (10 September) }\end{array}$ \\
\hline CoMgmt_NGO_DOY40 & $\begin{array}{l}\text { Difference of spline interpolated NBR values between the Comanagement and NGO periods for the dry } \\
\text { season ( } 9 \text { February) }\end{array}$ \\
\hline NGO_DOY253 & Spline interpolated NBR values during the NGO period for the wet season (10 September) \\
\hline NGO_DOY40 & Spline interpolated NBR values during the NGO period for the dry season ( 9 February) \\
\hline NGO_Trans_DOY253 & $\begin{array}{l}\text { Difference of spline interpolated NBR values between the NGO and Transitional periods for the wet season } \\
\text { (10 September) }\end{array}$ \\
\hline NGO_Trans_DOY40 & $\begin{array}{l}\text { Difference of spline interpolated NBR values between the NGO and Transitional periods for the dry season } \\
\text { (9 February) }\end{array}$ \\
\hline Transition_DOY253 & Spline interpolated NBR values during the Transitional period for the wet season (10 September) \\
\hline Transition_DOY40 & Spline interpolated NBR values during the Transitional period for the dry season ( 9 February) \\
\hline Trans_Derg_DOY253 & $\begin{array}{l}\text { Difference of spline interpolated NBR values between the Transitional and Derg periods for the wet season } \\
\text { (10 September) }\end{array}$ \\
\hline Trans_Derg_DOY40 & $\begin{array}{l}\text { Difference of spline interpolated NBR values between the Transitional and Derg periods for the dry season } \\
\text { (9 February) }\end{array}$ \\
\hline Derg_DOY253 & Spline interpolated NBR values during the Derg period for the wet season (10 September) \\
\hline Derg_DOY40 & Spline interpolated NBR values during the Derg period for the dry season (9 February) \\
\hline
\end{tabular}

variables and is robust to missing predictor data and (multi) collinearity (De'ath and Fabricius 2000). Random forest classifiers have been used in Ethiopia for a variety of objectives, including the identification of wetlands (Dubeau et al. 2017), mapping irrigated agriculture (Vogels et al. 2019), and predicting soil functional properties (Vågen et al. 2013).

We used the land classes defined by participants in the interviews to conduct this supervised classification. We selected a cloud-free image taken on 10 December 2016 because it aligned most closely with the dates of the workshops and the most current highresolution imagery available in Google Earth Pro. We collected 184 ground truth points immediately following the group interviews under the direction of participants, and used these ground truth points and the results of the group interview mapping exercises to guide the collection of 3060 additional data points from Google Earth (where high-resolution imagery was available for December 2016 across the study area). A total of 27 environmental variables (Table 1) were used to predict the land classes: the seven bands from Landsat 8 comprising surface reflectance in the visible, near infrared, and shortwave infrared spectral regions, three tasseled cap composites (Kauth and Thomas 1976) of those bands (brightness, greenness, wetness), fourteen metric images from remote-sensing based phenological models (described below), as well as elevation, aspect, and slope variables derived from a 30m ASTER Global Digital Elevation Model (NASA/METI/AIST/Japan Spacesystems and U.S./Japan ASTER Science Team 2009). See Appendix 1 for a map of training points (Fig. A1.2). Because there are no available aerial photographs or ground truth datasets for this area, we were not able to conduct a supervised classification for past time periods.

We used spline interpolation to explore general changes in phenology and vegetation productivity in the area using all available Landsat data from 1985 to the present $(n=597$ image dates). We performed standard cloud-masking on each image (Zhu and Woodcock 2012), and extracted Normalized Burn Ratio (NBR) values (Key and Benson 2006). NBR is similar to other vegetation indices like the more commonly employed Normalized Difference Vegetation Index (NDVI; Tucker 1979), except that it is calculated using the near-infrared and shortwave-infrared wavelengths, making it more resistant to atmospheric contamination. Although NBR has traditionally been used to detect the magnitude and direction of vegetation change pre- and postfire events (Key and Benson 2006), we found its resistance to atmospheric contamination and sensitivity to changes in both vegetation structure and moisture content to be useful in our cloudy study area.

The image stack was divided temporally into four date ranges corresponding to the duration of each political-management 
period for which satellite data were available. This resulted in 70 images in the Derg period ( 44 with $<50 \%$ cloud cover), 148 images in the Transition period ( 87 with $<50 \%$ cloud cover), 147 images in the NGO period ( 86 with $<50 \%$ cloud cover), and 232 in the Comanagement period ( 135 with $<50 \%$ cloud cover). The total number of cloud-free images for each pixel ranges from 31 to 454 with a mean of 322 images. A map is provided in Appendix 1 to illustrate that the Guassa area and kebeles immediately adjacent (Ferkuta, Yedi, and Dergagne) suffer from the highest cloud cover, yet still have 200-300 cloud-free images on average (Fig. A1.3).

To assess vegetation changes over these political-management periods, we used spline interpolation to model NBR values and estimate phenological curves at each pixel within each politicalmanagement period (Fig. A1.4). Spline interpolation allows for estimation of vegetation index values at every day of year (DOY) regardless of the timing of image acquisition (Clinton et al. 2010). This allowed us to select the best dates for comparison with local knowledge of the area rather than remaining restricted to the availability of particular satellite images. We derived maps of NBR values for wet (DOY 253, 10 September) and dry (DOY 40, 9 February) seasons for each period. We then subtracted maps of the earlier time period from the later time period to assess the magnitude and extent of changes in NBR, which we interpret as a measure of vegetation productivity. NBR can take values ranging from -1 to 1 , though values between -0.5 and 0.5 are more common in Guassa. Therefore, using a conservative approach based on a histogram analysis, we considered a significant decline in vegetation to be values $<-0.2$, and a significant increase in vegetation to be $>0.2$. Anything between -0.05 and 0.05 was considered to be negligible change. These outputs were analyzed individually as a measure of vegetation change, and served as inputs to the supervised classification described above.

We employed another time series dataset to explore changes in precipitation for the study area over the same time period, which we then compared to the changes in vegetation and narratives of change from group interviews. We used the Climate Hazards group Infrared Precipitation with Stations data (CHIRPS; Funk et al. 2015), processed through the Climate Engine Application (http://climateengine.org/), to look at past precipitation patterns over the study area, stretching from 1981 to 2018 (Fig. A1.5). CHIRPS data integrates $0.05^{\circ}$ resolution satellite imagery with available in-situ station data on precipitation to produce a gridded time series product that estimates precipitation every five days. We conducted a nonparametric Mann-Kendall test on the total annual precipitation in the belg and kiremt rainy seasons to assess trends in precipitation patterns over the past 37 years. We then used another nonparametric test (Kruskall-Wallis) to determine whether significant differences in precipitation occurred across the historical periods of interest, again with attention to the short belg and long kiremt rainy seasons. Statistical tests were conducted in R (R Core Team 2019). For all of these statistical tests, we considered $\mathrm{p} \leq 0.05$ to be statistically significant.

\section{Cointerpretation of results}

In August 2018, 41 participants (12 women and 29 men) were invited to attend a workshop in the town of Mehal Meda. Participants were invited from the Guassa Committee and the Tourism Board ( $\mathrm{n}=27$, three from each community), the Guassa Conservation office $(n=3)$, scientists and NGO workers $(n=6)$, and the local woreda administration office $(n=5)$. The workshop sought to bring together results from the ethnographic and remote sensing analyses, and to request feedback to help scientists validate and interpret the results. A second workshop was held in February 2019 to refine the results and analysis further, with mostly the same participants $(n=38)$. For example, we requested feedback on the accuracy of the supervised classification maps and vegetation change analyses, and whether they had ideas about the causes of the changes observed. We sought to ensure the remote sensing products were useful to local participants, so we incorporated suggestions like changing the colors used to represent different land classes and editing the location and extent of administrative boundaries.

\section{RESULTS}

\section{Locally defined land classes and their spatial distributions}

Across the nine kebeles, participants identified 10 land classes with local relevance. Using 27 environmental predictors (Table 1) and 3244 training points, we conducted a supervised classification of these locally defined land classes (Fig. 3). We fit 5000 trees with a random forest classifier, using cross-validation to assess model performance. The classifier had an overall accuracy of $87.1 \%$ and a kappa value of 0.85 , indicating a high quality performance. Across all land classes, the variables with the strongest influence on predictions, i.e., the largest mean decrease in accuracy, were elevation, wet season NBR values from the Comanagement period, dry season NBR values from the Derg period, and tasseled cap greenness. Yet, more nuanced patterns emerge at the level of individual land classes, where more densely vegetated classes (forest and shrublands) were better predicted by dry season NBR in the Derg and Comanagement periods, while less densely vegetated classes (stone and grazing lands) were better predicted by wet season NBR values in the Comanagement and Transitional periods. We present additional results in Appendix 1, including the confusion matrix (Table A1.1), a table of square kilometers per land class and percent area (Table A1.2), and a table of the relative importance of each predictor variable per land class (Table A1.3). Below, we present the land classes and their relative distributions in decreasing order of land area.

Farmland: The main crops of this region are barley, wheat, and beans. Different crop cultivars are planted depending on the season. Weeding and harvesting are often done through communal "Debo" groups, though farmland is privately owned. Farmland is the largest land class in the study area, occupying $161 \mathrm{~km}^{2}(36.1 \%)$ of the total land area, and between $29 \%$ and $59 \%$ of each kebele's land area. Averaging user's and producer's accuracies (Alonzo et al. 2014) revealed that farmland had a classification error of $15.1 \%$. Tasseled cap greenness and dry season NBR values during the Comanagement period were the best predictors of this land class.

Shrublands: Shrublands are composed of mainly short, dense species like asta (Erica arborea), amijah (Hypericum revolutum), and cheranfi (Euryops pinifolius), all of which are economically valuable species, though people are no longer allowed to harvest them inside Guassa because of potential impacts to wildlife. Shrubland occupies $69 \mathrm{~km}^{2}(15.5 \%)$ of the total land area, and is found mostly in Guassa $\left(21.8 \mathrm{~km}^{2}\right)$, though there are some concentrated areas primarily in Gragne, Kewula, and Yedi kebeles. Shrubland had the second largest error in classification 
Fig. 3. Classification of the study area using locally defined land classes.

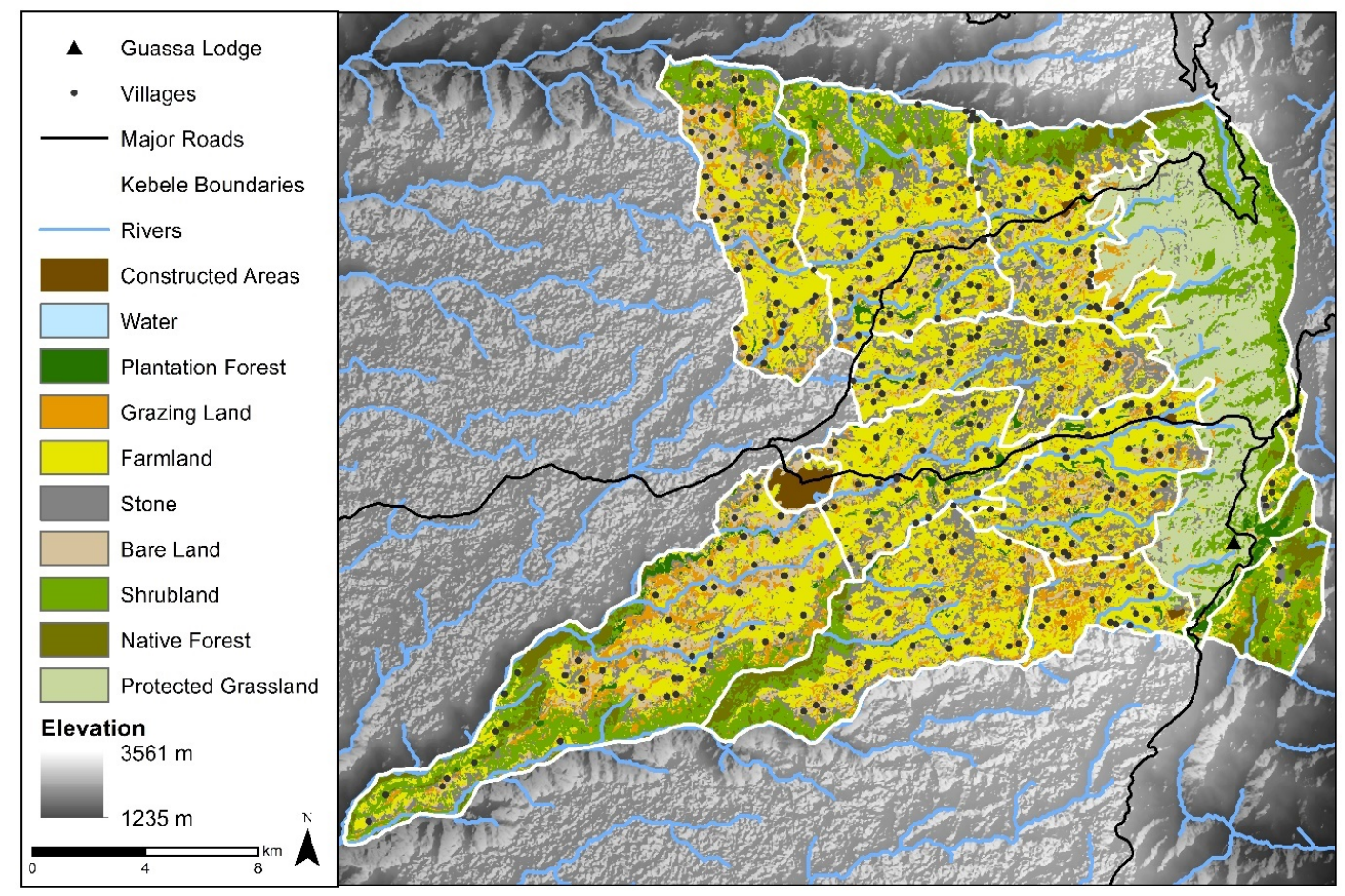

(17\%), primarily because of its spectral similarity with native forest. Band 4, slope, and dry season NBR during the Derg period were the best predictors of this land class.

Stone: This land class was described as a mix of exposed, rocky outcrops and the presence of large amounts of stone in the soil, to the point that it prevents using the land as farmland. Although stone occupies a large amount of total land area $\left(69 \mathrm{~km}^{2}, 15.5 \%\right)$, it is largely concentrated inside the kebele lands (mostly in Gragne, Kewula, and Chare kebeles) and is quite limited inside Guassa $\left(3.2 \mathrm{~km}^{2}\right)$. Stone had the largest errors in classification $(18.6 \%)$ and was often misclassified as farmland or bare land. Wet season NBR values from the Comanagement period and tasseled cap greenness were the best predictors of this land class.

Protected grasslands: Most of the land classes were used exactly as described by participants. However, when asking about the land classes within the Guassa area, people started listing individual species names rather than broader types of vegetation cover. There was then a consolidation process that resulted in the "protected grassland" class, which is made up of multiple grass and forb species. This is the only land class that contains the guassa grasses. Because of persistent confusion over the Guassa border, some of the protected grasslands fall into the administrative areas of the kebeles. The protected grasslands occupy $45.5 \mathrm{~km}^{2}(58.2 \%)$ of Guassa, with scattered patches in the adjacent kebele lands. Protected grasslands had a low classification error $(8.7 \%)$. Elevation and tasseled cap greenness were the best predictors of this land class.

Grazing lands: Grazing lands are communal lands, but are managed differently than the Guassa area because they do not have the same restrictions on access. One man explained that "if one man owns 50 sheep and another man owns one, the grazing area is still shared. But if he is enterprising enough, the man with one sheep can cut the grass and sell it to the rich man." Grazing lands are dominated by gaya grass (Andropogon abyssinicus). Grazing land occupies $39.7 \mathrm{~km}^{2}(8.9 \%)$ of the total land area, and between $6.1 \%$ and $15.3 \%$ of each kebele's land area. Grazing lands had a classification error of $13.6 \%$, and were most frequently confused with bare land. Band 6, Band 5, and wet season NBR values from the Comanagement and Transitional periods were the best predictors of this land class.

Bare lands: Bare lands are characterized by the absence of vegetation on land that should be able to support vegetation; it was also described as "old" or "tired" land that has potential to recover. Bare land occupies $33 \mathrm{~km}^{2}(7.4 \%)$ of the total area, most of which is found in Gragne, Kewula, and Tesfomentier kebeles. Bare lands had a classification error of $15.8 \%$. Band 4, Band 3, and Band 2 were the best predictors of this land class.

Native forest: Besides plantation forests, native forests are the only other type of forest in this area. However, it was difficult for participants to explain the difference between native forest and shrublands; many of the same species occur in both land classes, but native forest contains larger plants with different use values. Some of the larger species that occur in both land classes are kosso (Hagenia abyssinica), bisana (Croton macrostachyus), and juniper (Juniperus procera). Native forest occupies $15.9 \mathrm{~km}^{2}(3.6 \%)$ of the total land area, and is concentrated in Kewula, Kuledeha, Yedi, and Dargegne kebeles. There was no detectable amount of native forest in Chare kebele. Native forest had a classification error of $14.7 \%$. Dry season NBR values from the Derg period and Band 4 were the best predictors of this land class. 
Plantation forest: Plantation forests range in size depending on whether they were established as public erosion control projects or as private woodlots. There are two dominant plantation species in the area, eucalyptus (Eucalyptus globulus) and cypress (Cupressus lusitanica). Plantation forest occupies only $9.1 \mathrm{~km}^{2}(2 \%)$ of the total land area, which is distributed relatively evenly throughout the kebeles with a larger concentration in Guassa. Plantation forest had a low classification error (3.6\%). Dry season NBR values from the Comanagement and Derg periods and the difference in dry season NBR values between the NGO and Transitional periods were the best predictors of this land class.

Water: Open water was only present in one location in the study area, a small reservoir between Gedenbo and Chare kebeles. The two training points we used for this reservoir were both correctly classified. Streams were too small to be captured by this classification. Band 3, band 4, and dry season NBR values from the Comanagement period were the best predictors of this land class.

Constructed areas: Constructed areas are the areas where humans live and construct their houses and other buildings. Constructed areas had such an initially high class error that we removed it from the model and digitized the four cities, 50 churches, 22 schools, and approximately 380 villages by hand. The difficulty of accurately predicting constructed areas was partially due to the small size of individual homesteads, the brightness of tin roofs, and the presence of forest patches close to most residences, all of which led to confusion among constructed areas, farmland, plantation forest, stone, and bare land classes. Constructed areas and water reservoirs together comprise less than $1 \%$ of the landscape.

\section{Ranked preferences for ecosystem services by land class}

Participants ranked the importance of ecosystem services in each class except for bare land, which they perceived as having no ecosystem services, and constructed areas, which have so many benefits that it was perceived to be unrealistic to name them all. Participants in the first group interview chose to list benefits of Guassa ("Guassa Area" in Fig. 4) separately from those of the protected grasslands, and so we asked participants in subsequent interviews to continue with this distinction. For example, Guassa is a source for guassa grasses ("harvest guassa grass," Fig. 4), which then have their own set of associated ecosystem services (e.g., "roof thatch"). Salience values are used to rank ecosystem services across kebeles; values closer to one indicate good agreement across the nine kebeles regarding the importance of a particular ecosystem service.

Of these nine classes, seven had perfect agreement across the kebeles regarding the most important ecosystem service for that class. These were crops (farmland), forage (grazing land), roof thatch (guassa grass), guassa grass provisioning (Guassa area), firewood (shrubland), house construction (stone), and house construction (plantation forest). There was nearly unanimous agreement that drinking water is the most important service from the water class. Native forest services were not as uniformly valued, with the top four ecosystem services sharing similar salience values: income, household items, firewood, and house construction. This was also the only land class with income as the most important benefit, perhaps reflecting the subsistence orientation of people in this region. Indeed, the majority of ecosystem services described by participants would be considered "provisioning services," or products obtained directly from ecosystems, indicating the importance of these materials for the livelihoods of the participants.

Fig. 4. Locally defined land classes and their respective ecosystem services, ranked and aggregated across the nine kebeles. Colored squares indicate overlap of services with other land classes.

\begin{tabular}{|c|c|c|c|c|c|}
\hline Ranked Ecosystem Services & $\begin{array}{l}\text { Relative } \\
\text { Salience } \\
\text { (S score) }\end{array}$ & Overlap & Ranked Ecosystem Services & $\begin{array}{l}\text { Relative } \\
\text { Salience } \\
\text { (S score) }\end{array}$ & Overlap \\
\hline \multicolumn{3}{|l|}{ Farmland } & \multicolumn{3}{|l|}{ Shrubland } \\
\hline $\begin{array}{l}\text { Crops } \\
\text { Forage (straw) } \\
\text { Home gardens } \\
\text { traw for wall construction } \\
\text { Animal feed crops } \\
\text { Irrigation } \\
\text { Income }\end{array}$ & $\begin{array}{c}1 \\
0.44 \\
0.24 \\
0.04 \\
0.04 \\
0.04 \\
0.04\end{array}$ & unique & $\begin{array}{c}\text { Firewood } \\
\text { Shelter for wild animals } \\
\text { Honey } \\
\text { Soil protection } \\
\text { Household items } \\
\text { Broom construction }\end{array}$ & $\begin{array}{c}1 \\
0.58 \\
0.33 \\
0.31 \\
0.15 \\
0.08 \\
0.08\end{array}$ & unique \\
\hline \multicolumn{2}{|c|}{ Grazing Land } & & $\begin{array}{l}\text { Forage } \\
\text { Beauty }\end{array}$ & 0.04 & 口 \\
\hline Forage & 1 & 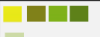 & House construction & 0.04 & प्वा \\
\hline $\begin{array}{l}\text { Fodder } \\
\text { Income }\end{array}$ & $\begin{array}{l}0.70 \\
0.27\end{array}$ & Lar & \multicolumn{2}{|l|}{ Water } & \\
\hline $\begin{array}{l}\text { Roof thatch } \\
\text { Grass for wall plaster } \\
\text { construction } \\
\text { Floor covering }\end{array}$ & $\begin{array}{l}0.04 \\
0.02\end{array}$ & 口ita & $\begin{array}{c}\text { Drinking } \\
\text { Food preparation } \\
\text { Washing } \\
\text { House construction }\end{array}$ & $\begin{array}{l}0.96 \\
0.82 \\
0.56 \\
0.39\end{array}$ & $\begin{array}{l}\text { unique } \\
\text { unique } \\
\text { unique }\end{array}$ \\
\hline \multicolumn{2}{|l|}{ Guassa Grass } & & Water for animals & 0.30 & unique \\
\hline $\begin{array}{l}\text { Roof thatch } \\
\text { Rope construction } \\
\text { Grass for wall plaster }\end{array}$ & $\begin{array}{c}1 \\
0.83\end{array}$ & unique & $\begin{array}{l}\text { Irrigation } \\
\text { Healing waters } \\
\text { Home gardens }\end{array}$ & $\begin{array}{l}0.24 \\
0.07 \\
0.04\end{array}$ & unique \\
\hline construction & $\begin{array}{l}0.62 \\
0.44\end{array}$ & 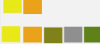 & \multicolumn{2}{|l|}{ Stone } & \\
\hline $\begin{array}{l}\text { Income } \\
\text { Sleeping mat }\end{array}$ & 0.26 & unique & House construction & 1 & 口n \\
\hline Fodder & 0.22 & & Fence construction & 0.69 & \\
\hline Floor covering & 0.18 & & Soil protection & 0.52 & $\square \square$ \\
\hline Local materials & 0.02 & unique & Income & 0.16 & प्रा \\
\hline \multicolumn{2}{|l|}{ Guassa Area } & & $\begin{array}{l}\text { Bridage construction } \\
\text { Road construction }\end{array}$ & $\begin{array}{l}0.10 \\
0.07\end{array}$ & $\begin{array}{l}\text { unique } \\
\text { unique }\end{array}$ \\
\hline $\begin{array}{l}\text { Harvest guassa grass } \\
\text { Source of water } \\
\text { Shelter for wild animals }\end{array}$ & $\begin{array}{c}1 \\
0.71 \\
0.47\end{array}$ & $\begin{array}{l}\text { unique } \\
\text { unique }\end{array}$ & $\begin{array}{l}\text { Building water infrastructure } \\
\text { Boundary demarcation }\end{array}$ & $\begin{array}{l}0.04 \\
0.02\end{array}$ & $\begin{array}{l}\text { unique } \\
\text { unique }\end{array}$ \\
\hline To attract tourism & 0.33 & unique & \multicolumn{2}{|c|}{ Plantation Forest } & \\
\hline $\begin{array}{c}\text { To attract rain } \\
\text { Harvest other plants }\end{array}$ & $\begin{array}{l}0.05 \\
0.04\end{array}$ & unique & $\begin{array}{l}\text { House construction } \\
\text { Firewood }\end{array}$ & $\begin{array}{c}1 \\
0.85\end{array}$ & 무 \\
\hline \multicolumn{2}{|c|}{ Native Forest } & & Income & 0.72 & 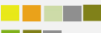 \\
\hline Income & 0.84 & 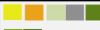 & Soil protection & 0.50 & 口a \\
\hline Household items & 0.83 & a & Household items & 0.41 & 口 \\
\hline Firewood & 0.80 & [0 & Shelter for wild animals & 0.31 & $\square$ \\
\hline House construction & 0.76 & (1) & To attract rain & 0.24 & 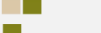 \\
\hline Forage & 0.50 & $\begin{array}{ll}101 \\
\end{array}$ & Climate regulation & 0.11 & an \\
\hline $\begin{array}{l}\text { Soil protection } \\
\text { Climate regulation }\end{array}$ & 0.50 & 口回 & $\begin{array}{c}\text { Forage } \\
\text { Fence construction }\end{array}$ & 0.08 & (1) \\
\hline $\begin{array}{l}\text { Climate regulation } \\
\text { To attract rain }\end{array}$ & $\begin{array}{l}0.25 \\
0.25\end{array}$ & 口 & $\begin{array}{l}\text { Fence construction } \\
\text { Shade }\end{array}$ & 0.07 & unique \\
\hline Shelter for wild animals & 0.24 & $\square$ & Honey & 0.03 & \\
\hline Cultural medicine & 0.13 & unique & Charcoal & 0.02 & unique \\
\hline To improve soil fertility & 0.06 & unique & To attract groundwater & 0.01 & unique \\
\hline Certain fruits & 0.03 & unique & Beauty & 0.01 & \\
\hline
\end{tabular}

Although there are several shared ecosystem services across the grazing land and protected grassland classes, clear distinctions arise under the particular socio-cultural and ecological context of this area. One difference is due to the types of grass found in these grasslands. Grazing lands produce grasses that are valued mainly as forage, while guassa grasses are considered valuable primarily for nonforage uses. Grazing is only allowed in the grazing areas because it has been banned inside Guassa since 2010. Even before the ban, it was only allowed every three to five years or under conditions of severe drought (Ashenafi and Leader-Williams 2005). The strength and height of the guassa grass makes it particularly desirable for rope making and other local materials such as ponchos, which are not valuable uses for the gaya grasses found in the grazing lands. Five shared services exist across these 
classes: brick and wall plaster construction materials, fodder, income, roof thatch, and floor covering. However, differences in the relative ranks of these shared ecosystem services further demonstrate the value of guassa grasses compared to other grass species. Roof thatch is unanimously considered the single most valuable service provided by the guassa grasses, and it is only the fourth most important for gaya grasses. Similarly, gaya grasses will be used for brick and wall plaster construction only when guassa grasses are unavailable. The relative position of income in these classes is illuminating because it indicates that people may tend to sell gaya grasses $(\mathrm{S}=0.27)$ before using them for construction materials $(S=0.04)$. Likewise, people may tend to sell guassa grasses $(\mathrm{S}=0.44)$ before using them for fodder $(\mathrm{S}=$ 0.22 ). These differences in ecosystem services demonstrate a complementary relationship between the different types of grasslands in the area.

There are noteworthy similarities and differences in the ecosystem services received from shrubland, native forest, and plantation forest classes that illustrate how these classes interact to support local livelihoods. All three classes provide six shared ecosystem services: firewood, household items, house construction materials, forage, soil protection, and shelter for wild animals. However, the relative importance of these benefits varies among the land classes. For example, the most important benefit received from plantation forest is timber for house construction, while this is the ninth most important benefit from shrublands. The second most highly valued benefit of shrublands is the shelter they provide for wild animals, while this is valued much less in native and plantation forests. The second most highly valued benefit from native forest is household items, while this is valued fifth for both plantation forest and shrublands. Despite having similar species compositions, there are no further similarities in services between shrublands and native forest. However, there are two additional shared services between shrublands and plantation forest and three additional shared services between plantation forest and native forest. Shrublands and plantation forest are both valued for bee-keeping (honey production) and for their beauty, whereas plantation forest and native forest are both valued for the income opportunities they bring and for their role in climate regulation and the perceived ability to attract rain. Shrublands have one unique service apart from native or plantation forest (broom construction). Plantation forest has four unique ecosystem services: fence construction, shade, charcoal production, and the ability to increase groundwater (though this last is restricted to cypress and not eucalyptus). Native forest has three unique ecosystem services: traditional medicine, local fruits, and the ability to improve soil fertility.

\section{Local narratives of change}

We constructed timelines of change for each of these land classes by looking for consistent patterns and narratives across the group interviews. When explanations diverged, we sought additional explanations and clarity during the cointerpretation workshops. We present the classes in order of decreasing consensus, first highlighting classes where participants reported similar perceptions of change.

Bare lands: All participants agreed that bare land has been increasing in the kebele lands since the Derg period because of declines in soil fertility and precipitation, combined with intensive grazing and increased soil erosion. However, bare land has been decreasing inside Guassa since the NGO period because of improved management activities and decreased human activity.

Constructed areas: All participants agreed that humanconstructed areas have been increasing since the Derg period because of an increasing local population (from births, not immigration). In addition to new villages and individual farmsteads, small cities are emerging in three communities nearest to Guassa as good farmland becomes increasingly scarce and as people in the area desire better access to urban resources and lifestyles.

Grazing lands: All participants agreed that grazing land area has been decreasing since the Derg period because of conversion to farmland. During the Imperial period, the lands immediately west of Guassa were communal grazing lands, but are now predominantly farmland and constructed areas. Participants reported that large communal grazing lands are becoming less common, and farmers are increasingly setting aside marginal farmland to use as private grazing areas. Grazing near streams and rivers has also increased.

Plantation forest: All participants agreed that plantation forests have been increasing since the Derg period. Plantations were rare during the Imperial period, and communities would travel 100 $\mathrm{km}$ for construction-quality timber. The Derg government planted large plantations early in the regime, primarily as a soil and water conservation strategy. By the fall of the Derg 17 years later, plantation forests were well established. Smaller community and private plantations have been increasing in number and extent since the Transition period, and most participants want this expansion to continue because of the variety of novel ecosystem services they bring to the region.

Stone: All participants agreed that rocky areas have increased as soil erosion has exposed more stones, particularly since the Transition period.

Protected grasslands: All participants agreed that both the quality and extent of the protected grasslands have varied in direct response to changes in management regimes over the last 40 years. During the Imperial period, access to the area was heavily regulated and the species composition was less diverse as guassa grasses dominated. During the Derg and Transitional periods, the nine kebeles no longer had the legal right to exclude people from using the area. This resulted in a large increase in grazing as well as grass and firewood harvesting inside Guassa from people within and outside the nine kebeles. Some people from the kebeles nearest Guassa converted areas of Guassa to farmland. During the NGO period, as communities struggled to regain land tenure rights to Guassa, farmers who had moved into Guassa were evicted and grassland quality slowly improved. The area was last opened for the traditional grass harvest, grazing, and firewood collection for two months in 2006, followed by nine years of closure to "let the area recover" from heavy use in the 1980s and 1990s. In 2010, people in charge of Guassa management decided to stop allowing grazing and firewood collection entirely. The area has since been opened exclusively for guassa grass harvest for a period of 10 to 15 days in the spring of 2015 and again in 2018 . Overall, participants celebrated the regreening of the Guassa area as an important conservation victory. 
Water: Most participants (eight kebeles) reported a decrease in the surface water quantity available on the landscape since the Derg period because smaller, ephemeral streams are filling with sediment and limiting their ability to hand-irrigate nearby farmland. Some perceived the establishment of borehole wells to have made up for those losses. One kebele (Chare) reported increasing water because of the creation of a reservoir.

Farmland: Some changes to farmland had good agreement among the participants. For example, people did not farm near Guassa during the Imperial period. However, an increasing population coupled with villagization programs, i.e., the creation of new villages, during the Derg period (Ashenafi and LeaderWilliams 2005) led to increased agricultural land use in areas close to Guassa. However, different narratives arise over changes in extent of farmland since the Transition period: most participants (seven kebeles) said farmland area is decreasing because of higher rates of erosion and loss of soil fertility, leading people to leave the land fallow, convert it to grazing land, build houses on it, or plant eucalyptus plantations. One kebele (Gedenbo) maintained that farmland area has not changed, while another kebele (Kewla) said farmland area is increasing as grazing lands are converted to row crops. Despite these different narratives of change to farmland area, all kebeles were unified in the belief that farmland quality has declined since the Derg period, citing loss of soil fertility and a disappearing belg rainy season that stopped coming reliably in the early 1990s. One participant explained "we used to harvest twice a year, so the yields used to be higher ... but the belg rains have reduced, and sometimes we only harvest once a year now." Declines in soil fertility and precipitation have required various adaptations in farming practices, including increased fertilizer use, new irrigation infrastructures, and new preferred cultivars of wheat and barley.

Native forest: The majority of participants (seven kebeles) reported that native forest was common during the Imperial period, but that it has since declined in both quality and extent. Participants said much of the area that is now shrublands in the northern ravines used to be dense native forest, but intensive harvesting of larger species like kosso, bisana, and juniper over the past few decades has turned it into shrublands similar to those found within Guassa and along the eastern escarpment. One kebele (Dargegne) reported that native forest has increased in their region because of improved local conservation. Chare reported there was never any significant areas of native forest in their region, which was supported by our classification and vegetation analysis.

Shrublands: Participants made a distinction between shrublands located in the kebele lands and those located inside Guassa. Four kebeles (Kewla, Gedenbo, Kuledeha, and Tesfomentir) reported that their kebele shrublands have been declining from overuse by local people, including illegal charcoal producers from the nearby Yifat woreda. Three kebeles (Ferkuta, Dergegne, and Yedi) reported that kebele shrublands have been increasing because of improved local conservation, and two kebeles (Chare and Gragne) reported there were never any significant areas of shrublands in their kebeles. However, all participants agreed that Guassa shrublands have been expanding since the NGO period. One nuisance shrub in particular, nachillo (Helichrysum splendidum), has been expanding rapidly, with no value for either people or wildlife.

\section{Vegetation changes}

Results indicate that although there are differences in NBR change across wet and dry seasons in the same time period (Fig. 5), general trends emerge that can be brought into conversation with the local narratives of change presented above to produce a more holistic understanding of change (Fig. 6). Between the Derg and Transition period, NBR generally increased across the study area ( $11.8 \%$ dry season, $62 \%$ wet season). In fact, NBR decrease occurred over an extremely small area of the total landscape $(1.8 \%$ dry season, $0.93 \%$ wet season). Guassa experienced NBR increase in $30.4 \%$ of its area in the dry season and $69.3 \%$ of its area in the wet season, which contradicted local narratives of increased resource use and extraction during this period. NBR decrease was concentrated in Ferkuta (4.1\% of kebele area) and Yedi $(9.7 \%$ of kebele area) during the dry season.

Fig. 5. Normalized Burn Ratio change across four periods of political and management history. Column (a) shows dry season change, whereas column (b) shows wet season change. The first row shows change between the Transition period (1991 - 2003) and Derg period (1985 - 1991), the second row shows the NGO period (2003 - 2012) minus the Transition period, and the third row the CoManagement period (2012 2017) minus the NGO period. The fourth row shows the overall change across the entire Landsat record (CoManagement minus Derg). Note that wet season results in the first and second rows are being influenced by the scan-line corrector failure in Landsat 7, resulting in some striping patterns that are not a reflection of vegetation change on the landscape.

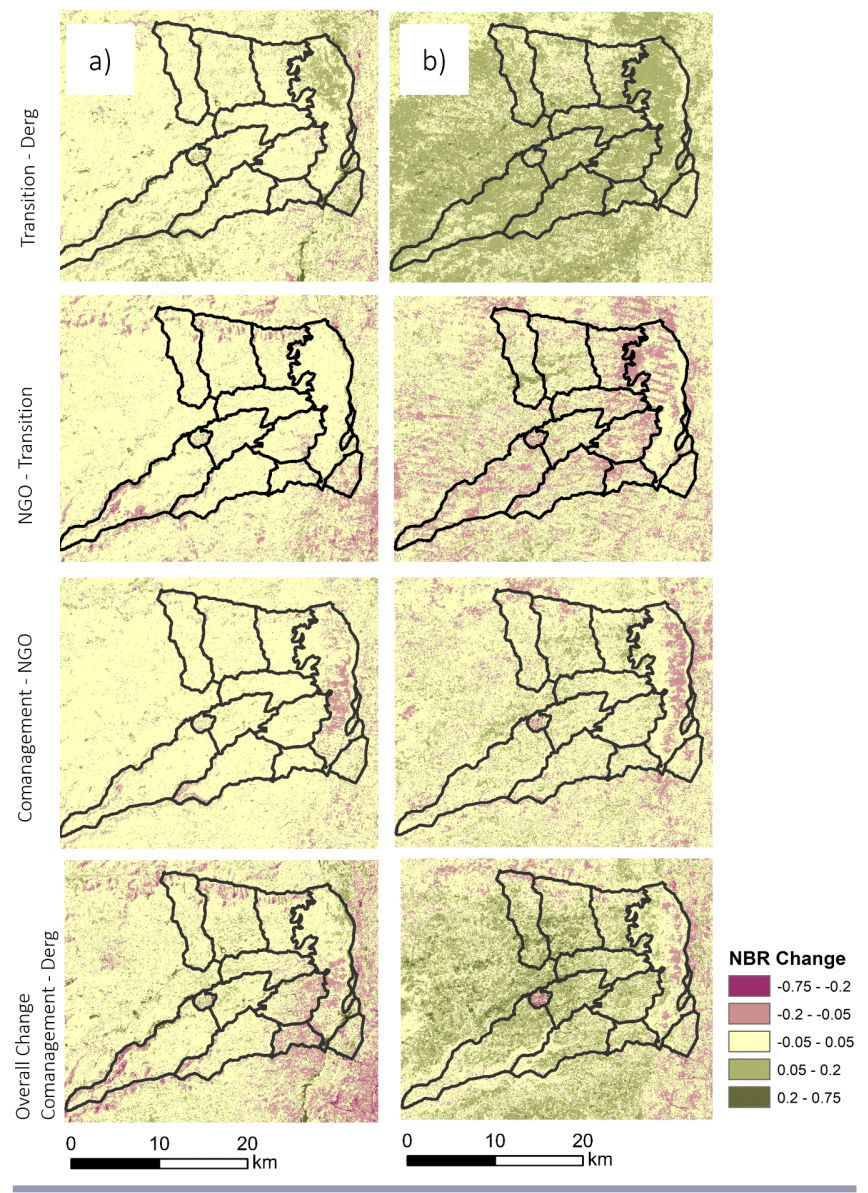


Fig. 6. Timeline of change across multiple data sources.

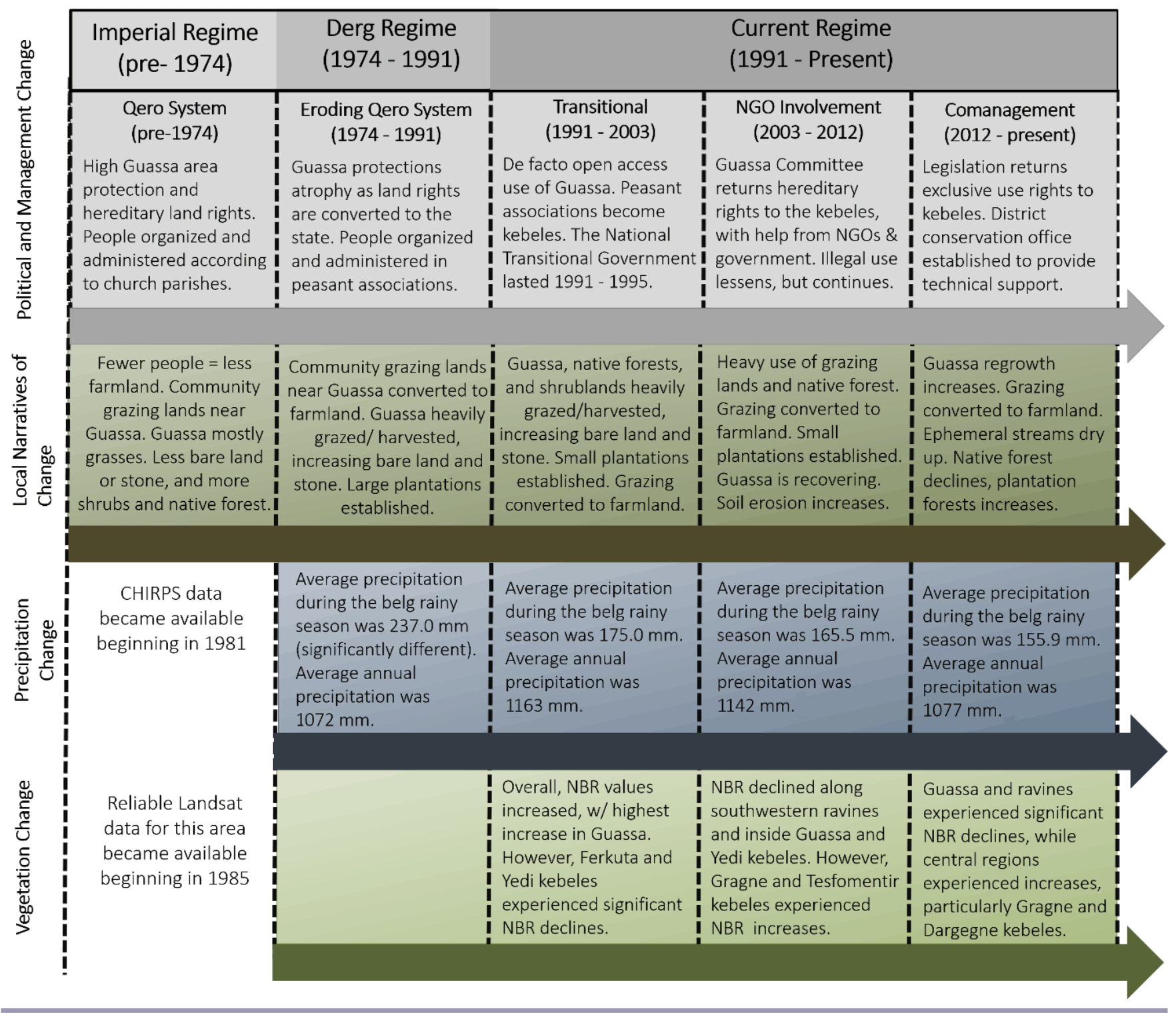

From the Transition to the NGO period, NBR generally decreased across the total landscape (8.2\% dry season, $27.5 \%$ wet season). These decreases were widespread across the landscape in the wet season, but disproportionately impacted the ravines in Dargegne (12.7\% of kebele area), Kewula (14.6\% of kebele area), and Yedi (18.4\% of kebele area) in the dry season. NBR increases were small across the entire landscape $(2.3 \%$ dry season, $6.3 \%$ wet season) and located primarily in Gedenbo (11.5\% of kebele area), Gragne ( $16.1 \%$ of kebele area), and Tesfomentir $(15.2 \%$ of kebele area) in the wet season.

From the NGO to the Comanagement period, NBR generally decreased across the landscape $(6.5 \%$ dry season, $10.1 \%$ wet season), though NBR increases were also widespread in the wet season ( $2.2 \%$ dry season, $10.6 \%$ wet season). NBR decreases were most pronounced in the southern ravines and in Guassa, which contradicted local narratives of conservation success during this period. NBR increases were concentrated mostly in Dargegne (19.8\% of kebele area) and Gragne (18.4\% of kebele area) in the wet season.

Vegetation change across the entire time period, i.e., between Comanagement and Derg periods, revealed particularly severe dry season NBR declines in the northern and southern ravines and in the southeastern parts of Guassa, Ferkuta, and Yedi. Overall change in the wet season showed general NBR increase in the kebele lands and patches of NBR decrease inside the Guassa area. Of the land classes, only water and plantation forest showed a significant change (NBR change $+/-0.2$ ) across the study area. The mean NBR change across all plantation forest pixels was 0.2 in the dry season, though the increase was lower in Tesfomentier and higher in Guassa (Table A1.6). Water NBR values increased 
in Chare and Gedenbo because of the creation of the reservoir. Bare land NBR values increased in Gragne, i.e., bare land became more vegetated, while grazing land NBR values increased in Gedenbo. Farmland NBR values increased in all but Dergagne and Yedi. Native forest showed overall decrease in Gragne, Kewula, and Tesfomentier, and an overall increase in Ferkuta and Gedenbo (Table A1.6). Although Dergagne kebele reported native forest increase in the local narratives, we did not see this in the vegetation analysis. See Appendix 1 for a detailed breakdown of percent land area and direction of NBR change for each kebele and each time period, separated by wet season (Table A1.4) and dry season (Table A1.5), and a summary of overall mean NBR change values by land class (Table A1.6).

\section{Precipitation changes}

The precipitation analysis supported local narratives of a delayed and disappearing belg rainy season (Fig. 7). The Mann-Kendall tests revealed a significant decreasing trend in precipitation during the belg season $(\tau=-0.31, p=0.01)$. However, there was no significant trend in either the total annual precipitation $(\tau=0.09$, $p=0.46)$ or the kiremt season precipitation $(\tau=0.15, p=0.20)$. The Kruskall-Wallis tests indicate a significant difference in belg precipitation values across the four periods of political and management change $\left(\chi^{2}=8.13, p=0.04\right)$. The average belg precipitation during the Derg regime was $237 \mathrm{~mm}$, falling to 175 $\mathrm{mm}$ (Transitional period), $165 \mathrm{~mm}$ (NGO period), and finally 162 $\mathrm{mm}$ (Comanagement period). Again, no significant differences were detected across these political-management periods for the kiremt precipitation $\left(\chi^{2}=4.21, p=0.24\right)$ or total annual precipitation $\left(\chi^{2}=1.79, p=0.61\right)$.

Fig. 7. Trends in kiremt season ( $\sim 1$ July -30 September $)$, belg season ( $1 \mathrm{Feb}-30$ April), and total annual precipitation. Red lines indicate a lowess smoothing function applied across the entire time series. Vertical lines indicate the four periods of political and management change. Box plots illustrate differences in median and range of precipitation across those four periods. The star indicates a significantly higher belg season precipitation during the Derg period.

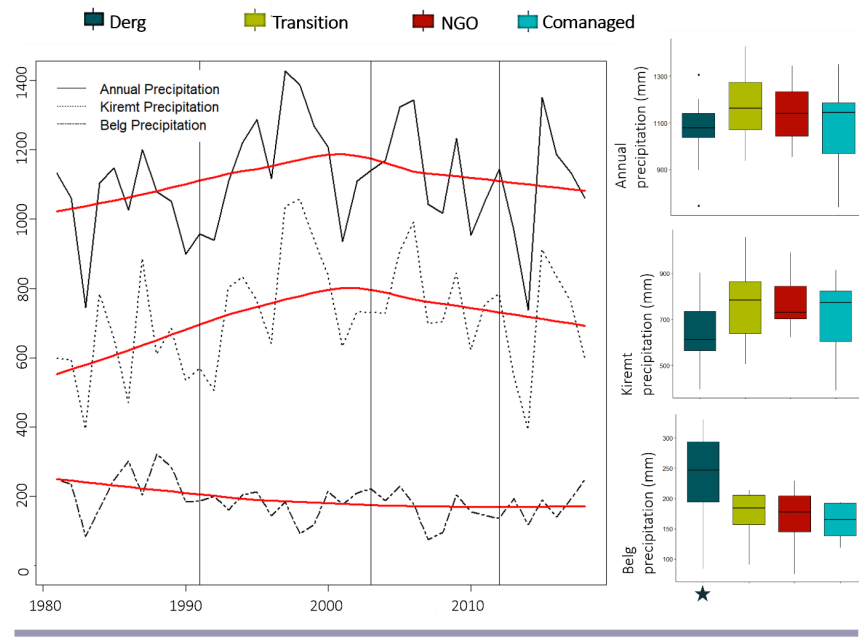

\section{DISCUSSION}

The iterative MEB process improved our project in multiple ways. First, local participants had time to reflect and become more comfortable with interpreting scientific products, and were offered the chance to refute or add nuance to the interpretation of remote sensing results. This produced a more holistic understanding of environmental change. Second, feedback from local participants ensured final products were valid and relevant to their needs and objectives. Although not every analysis was considered valid or relevant to every participant group, the process resulted in mutual benefits for both science and management. Third, the identification of uncertainties and contradictions across knowledge systems encouraged new learning. These differences point to productive areas of future research to enhance our understanding of the Guassa socialecological system.

Knowledge coproduction yields holistic understanding of change In our study, local knowledge provided a fine-grained perspective of place-based environmental change, offering the potential to extend interpretation of our remote sensing analysis back in time in the absence of other ground truth data (Herrmann et al. 2014, Eddy et al. 2017). Similarly, the broad spatial scale of the remote sensing analysis enabled us to extend the situated local knowledge of a limited number of participants across the entire study area. The temporal continuity of local knowledge is one of the reasons it is so valuable for interpreting remote sensing time series (Verburg et al. 2011, Smith et al. 2019), yet temporal biases have been observed in other studies that should be recognized. For example, people tend to view the past move positively than the present (Hermann et al. 2014); emotional experiences tend to influence the way people describe those years (Daw 2010); and general trends are sometimes less noticeable compared to extreme events because of a "shifting baseline" (Pauly 1995, Eddy et al. 2017). Remote sensing also experiences biases, notably from sensor, solar, atmospheric, and topographic effects that require extensive preprocessing (Young et al. 2017) and the disconnect sometimes observed between satellite-derived trends and the reality of ground conditions (Hermann et al. 2014, Eddy et al. 2017).

Our analysis demonstrates the complementarity of these approaches, illustrating some ways they worked to overcome each other's biases. For example, the remote sensing products were particularly effective for prompting participants to discuss what was happening around different dates of interest and how that might have impacted vegetation patterns on the landscape. This encouraged participants to move beyond their recollection of only high-profile, extreme events (Nazarea 2006, Daw 2010). For example, the rise and fall of the Derg regime were two extreme change points that were referred to repeatedly throughout the group interviews. By contrast, the vegetation change analysis instigated a new conversation about the ways in which NGO involvement unexpectedly triggered a brief episode of environmental degradation. It was during a local election in 2005, when one of the candidates ran on a platform telling everyone that "the white people stole your Guassa!" and that he would get it back for them if he was elected. Illegal grazing and harvesting increased during the months afterward because people believed the Guassa area had been sold to foreigners and this perceived land tenure insecurity led to unsustainable resource extraction. 
This recollection was prompted by the observed declines in NBR values during this period, which contradicted local narratives that said overall, Guassa was recovering (Fig. 6). Stories like these, instigated by the remote sensing analysis, revealed the direct impact that Guassa's protected status has on peoples' behavior, reflecting the importance of secure land tenure throughout the highlands (Lanckriet et al. 2015).

The iterative MEB process allowed us to reflect on our learning over time and build more nuanced understanding of change across these multiple knowledge systems. In our first workshop, participants immediately attributed areas of vegetation decline to local behaviors related to changing land tenure and management (e.g., overgrazing or lack of soil conservation activities) rather than a result of biophysical differences across kebeles (e.g., precipitation or soil fertility). In the second workshop, we introduced the precipitation analysis and multiple vegetation change maps across different days of the year in response to participant uncertainties regarding the impact of seasonal activities on NBR. Participants in the second workshop, who were almost entirely the same individuals, then proposed more nuanced explanations for how regional to global drivers of change were interacting with local behaviors to produce the patterns observed in the maps. For example, we noticed the kebeles closest to Guassa, and particularly Yedi kebele, seem to be experiencing the greatest vegetation losses over time. Participants explained that the kebeles closest to Guassa experience different precipitation patterns, which is supported by scientific observations of the rain shadow produced by orographic rainfall in the Ethiopian highlands (Dinku et al. 2011). The rain is therefore less abundant and less consistent in areas close to Guassa, causing farmers to rely more heavily on two growing seasons to accumulate enough crops to meet subsistence needs. The loss of the belg rainy season is thus causing a shift in farmer behavior across the study area; farmers farther from Guassa are more likely to shift to a single growing season, while farmers closest to Guassa are not willing to risk this change. These differences in perceived risk and behavior change were thought to have impacted the spatial patterns of NBR change observed at the kebele level (Figs. 5 and 6).

\section{Mutual benefits for science and management}

Our findings support the idea that projects that draw on a diversity of knowledge systems can produce new knowledge with high validity and utility across diverse participants (Laidler 2006, Armitage et al. 2011, Berkes 2012). For example, our MEB approach resulted in maps that contributed to the ability of Guassa area managers to understand and react to environmental change. Local knowledge further enabled us to contextualize this environmental change in terms of ecosystem services affected (Naidoo and Hill 2006). Anderson et al.'s land cover classification is widely used by remote sensing analysts and considers stone and bare land to be part of the same land cover class (Anderson et al. 1976). However, local participants rejected merging these two classes in the supervised classification because of the extreme differences in ecosystem services provided by them. Participants explained it was important to distinguish these classes spatially because bare land has much higher potential for reclamation than does stone, so identifying specific locations helped administrators target their conservation and restoration activities. In the workshops, local participants listed several benefits and uses for the supervised classification maps, including to help delineate and agree on boundaries, to advertise for tourism, to identify bare lands for restoration projects, and to facilitate long-term planning. These maps characterized the landscape using land classes that were meaningful to local residents in terms of the ecosystem services they provided, which increased their perceived value.

Tailoring the maps to local understandings of the landscape also produced unexpected and useful information for scientists. Grazing lands and protected grasslands were separated in the classification as a result of local knowledge about differences in species composition and land uses. An examination of the ecosystem services provided by these two types of grassland helped us identify potential differences in ecosystem function that may translate to broader implications for soil fertility and carbon storage. For example, the high value of guassa grass as a construction material indicates that it may be more recalcitrant, slower to decompose, and lead to more carbon accumulation in soil compared to grazing land grasses that are higher quality forage (De Deyn et al. 2008). Although the implications of these findings are beyond the scope of this paper, they were important results to discuss as a group because although the guassa grass is a cultural keystone species providing unique and valuable ecosystem services, very little is known about its ecological role in the conservation area.

Our findings emphasize the importance of achieving a balance between internally valid observations, and observations that carry weight and meaning across knowledge systems (Tengö et al. 2014). From a scientific perspective, the NBR and CHIRPS change results were rigorous and helpful for triangulating our spatial and temporal observations of change. However, these analyses were not considered particularly useful by local participants, who viewed them as providing different perspectives on the same problem. "We told you this the last time you came," they said to the researchers. "Your research keeps showing us the problem ... we need research that shows us the solution." Local participants felt that their descriptions of precipitation and vegetation change did not need to be confirmed by these additional sources, even though contradictions arose between the different types of knowledge. These results point to the role of compromise in collaborative environmental research, indicating that all participants need not find the same value in all aspects of the project in order for successful knowledge coproduction to occur.

\section{Uncertainty and contradiction encourage new learning}

Although the general results of our classification and vegetation change analysis reflect those of other studies in the Ethiopian highlands, for example, the timing of vegetation declines and emergence of plantation forests (de Mûelenaere et al. 2014, Jacob et al. 2016), we also observe some differences with other studies conducted in the region. Our precipitation change results indicate that the vegetation changes observed are likely not due to differences in precipitation across time periods, though the significantly higher belg precipitation during the Derg period may have influenced the increasing NBR values from the Derg to Transition periods to some degree. These results differ from other studies that show a strong relationship between precipitation variation across time periods and particularly woody vegetation cover (Annys et al. 2017). One potential explanation for these 
differences is the relatively high mean annual precipitation of the Guassa area compared to other places in the highlands; vegetation in wetter areas does not always respond in direct and proportional ways to precipitation (Rishmawi et al. 2016) and woody vegetation in particular shows a saturating relationship with precipitation whereby maximum tree cover is observed at any level above 650 $\mathrm{mm}$ (Sankaran et al. 2005). To better quantify and explain these differences, future research should focus on a more nuanced analysis of antecedent rainfall and attempt to decouple the impacts of climate from other impacts to vegetation (Eddy et al. 2017).

Our findings revealed a need for greater attention to the spatial and temporal variability of environmental change across this seemingly homogeneous cultural landscape. Farmland, stone, and shrublands occupy the largest land areas in the region, yet farmland and shrublands also have some of the greatest inconsistencies among local narratives of change, while stone and shrublands have some of the highest classification errors (though still within acceptable error ranges). These inconsistencies and errors indicate there is a need for improved understanding of variability within these dominant land classes, as kebeles may be experiencing different changes to those classes across the landscape. On the other side of the spectrum, careful attention is also required for the land classes with the smallest land areas. Native and plantation forest occupy the smallest areas across the kebeles, yet provide the highest number of ecosystem services. Many of the ecosystem services found in native forest, plantation forest, and shrublands are overlapping, and that redundancy may act as a buffer against future environmental change (RaudseppHearne et al. 2010) for the most important ecosystem services. However, lesser valued services found exclusively in native forest are doubtlessly facing eradication given the high agreement across knowledge systems that this land class is rapidly declining in both area and quality (Fig. 6). Our MEB approach thus enabled us to assist decision makers in understanding the need to assess how each kebele is differently impacted by ongoing environmental, land use, and land tenure change.

Although our MEB approach revealed multiple complementary findings across knowledge systems, we also identified compelling areas of disagreement that point to areas for future research. The most pronounced contradiction between local narratives of change and the vegetation change analysis regarded the health of vegetation within Guassa. Local narratives focused on local grazing and firewood harvesting practices, maintaining that Guassa was experiencing a regreening period after decades of unsustainable use caused by insecure land tenure. However, the remote sensing analysis revealed large areas of vegetation decline in Guassa since 2003 using NBR as an indicator of vegetation productivity and structure (Fig. 6). Iterative conversations at the coproduction workshops revealed that nachillo, a native shrub considered by locals to be a pest, had been expanding within the grasslands since about 1995. Given the differences in vegetation structure between the shrubs and grasses, we determined it was likely that this change in species composition was responsible for the moderate declines observed in NBR values. Specifically, we posit that shifts from satellite detection of primarily photosynthetic vegetation to woody shrubs with low leaf area could depress near infrared reflectance and increase shortwave infrared reflectance. Thus, these differences in spectral signatures led scientists to initially interpret the remote sensing results as contradictory to the regreening trends observed by locals. The invasion of this shrub is considered a threat to the future sustainability of Guassa as it appears to be competing with the guassa grasses for habitat. Because of the potential impacts on ecosystem function and ecosystem services, we collectively agreed shrub encroachment was the most valuable issue to address next using our coproduction process. This process of discovering new insights and ideas for future study is an integral part of knowledge coproduction, which emphasizes the importance of investigating contradictions rather than concealing or overlooking them (Huntington et al. 2004, Moller et al. 2004, Gagnon and Berteaux 2009, Gearheard et al. 2010, Etienne 2013, Klein et al. 2014, Tengö et al. 2014).

\section{CONCLUSION}

In this paper, we present the results from a multiple evidence based (MEB) approach (Tengö et al. 2014) to knowledge coproduction, which brought together insights from local and scientific knowledge using ethnographic and remote sensing methods. We produced a holistic understanding of environmental change in a community-protected grassland in the Ethiopian highlands, informing potential impacts on locally defined land classes and their associated ecosystem services. Our results highlight how integrating local and scientific knowledge can reveal gaps in system understanding, and how contradictory observations across knowledge systems can inspire new understanding and future research. Our project emphasizes the value of iterative approaches that allow local participants to more confidently inform remote sensing interpretations, and in turn allow scientists to clarify translations and interpretations so that local knowledge is accurately represented.

Responses to this article can be read online at: http://www.ecologyandsociety.org/issues/responses. php/11325

\section{Acknowledgments:}

This work was supported by The Rufford Foundation [\#23171-2]; Colorado State University's Graduate Degree Program in Ecology; the Center for Collaborative Conservation; The Murulle Foundation; and the Jim Ellis Memorial Scholarship. This work was also supported by funding from the U.S. National Science Foundation, including the National Socio-Environmental Synthesis Center (SESYNC) (\#DBI-1052875), the Mountain Sentinels Research Coordination Network (\#1414106), the I-WATER IGERT program (\#0966346), and a Geography and Spatial Sciences Doctoral Dissertation Research Improvement Award (\#1821288). We are grateful to the many research assistants and local participants from the Guassa area communities who made this work possible, and to the two anonymous reviewers for their helpful insights and suggestions. 


\section{LITERATURE CITED}

Admassie, Y. 2000. Twenty years to nowhere. Property rights, land management and conservation in Ethiopia. Red Sea Press, Trenton, New Jersey, USA.

Agrawal, A. 1995. Dismantling the divide between indigenous and scientific knowledge. Development and Change 26(3):413-439. https://doi.org/10.1111/j.1467-7660.1995.tb00560.x

Alonzo, M., B. Bookhagen, and D. A. Roberts. 2014. Urban tree species mapping using hyperspectral and lidar data fusion. Remote Sensing of Environment 148:70-83. https://doi. org/10.1016/j.rse.2014.03.018

Anderson, J. R., E. E. Hardy, J. T. Roach, and R. E. Witmer. 1976. A land use and land cover classification system for use with remote sensor data. Geological Survey Professional Paper 964. U.S. Geological Survey, Reston, Virginia, USA. https://doi. org/10.3133/pp964

Annys, S., B. Demissie, A. Z. Abraha, M. Jacob, and J. Nyssen. 2017. Land cover changes as impacted by spatio-temporal rainfall variability along the Ethiopian Rift Valley escarpment. Regional Environmental Change 17(2):451-463. https://doi.org/10.1007/ s10113-016-1031-2

Armitage, D., F. Berkes, A. Dale, E. Kocho-Schellenberg, and E. Patton. 2011. Co-management and the co-production of knowledge: learning to adapt in Canada's Arctic. Global Environmental Change 21(3):995-1004. https://doi.org/10.1016/j. gloenvcha.2011.04.006

Ashenafi, Z. T., T. Coulson, C. Sillero-Zubiri, and N. LeaderWilliams. 2005. Behaviour and ecology of the Ethiopian wolf (Canis simensis) in a human-dominated landscape outside protected areas. Animal Conservation 8(2):113-121. https://doi. org/10.1017/S1367943005001952

Ashenafi, Z. T., and N. Leader-Williams. 2005. Indigenous common property resource management in the central highlands of Ethiopia. Human Ecology 33(4):539-563. https://doi. org/10.1007/s10745-005-5159-9

Berkes, F. 2007. Community-based conservation in a globalized world. Proceedings of the National Academy of Sciences 104 (39):15188-15193. https://doi.org/10.1073/pnas.0702098104

Berkes, F. 2012. Sacred ecology. Fourth edition. Routledge, New York, New York, USA.

Berkes, F., and M. K. Berkes. 2009. Ecological complexity, fuzzy logic, and holism in indigenous knowledge. Futures 41(1):6-12. https://doi.org/10.1016/j.futures.2008.07.003

Berkes, F., J. Colding, and C. Folke. 2003. Navigating socialecological systems: building resilience for complexity and change. Cambridge University Press, Cambridge, UK. https://doi. org/10.1017/CBO9780511541957

Borgatti, S.P. 1996. ANTHROPAC 4.0. Analytic Technologies, Natick, Massachusetts, USA.

Breiman, L. 2001. Random forests. Machine Learning 45(1):5-32. https://doi.org/10.1023/A:1010933404324

Buitenwerf, R., L. Rose, and S. I. Higgins. 2015. Three decades of multi-dimensional change in global leaf phenology. Nature Climate Change 5(4):364-368. https://doi.org/10.1038/nclimate2533
Carpenter, S. R., H. A. Mooney, J. Agard, D. Capistrano, R. S. DeFries, S. Diaz, T. Dietz, A. K. Duraiappah, A. Oteng-Yeboah, H. M. Pereira, C. Perrings, W. V. Reid, J. Sarukhan, R. J. Scholes, and A. Whyte. 2009. Science for managing ecosystem services: beyond the Millennium Ecosystem Assessment. Proceedings of the National Academy of Sciences 106(5):1305-1312. https://doi. org/10.1073/pnas.0808772106

Cash, D. W., W. C. Clark, F. Alcock, N. M. Dickson, N. Eckley, D. H. Guston, J. Jäger, and R. B. Mitchell. 2003. Knowledge systems for sustainable development. Proceedings of the National Academy of Sciences 100(14):8086-8091. https://doi.org/10.1073/ pnas. 1231332100

Central Statistical Agency of Ethiopia (CSA). 2017. Population size by kebele, Menz Gera Woreda. CSA, Addis Ababa, Ethiopia.

Chalmers, N., and C. Fabricius. 2007. Expert and generalist local knowledge about land-cover change on South Africa's Wild Coast: Can local ecological knowledge add value to science? Ecology and Society 12(1):10. https://doi.org/10.5751/es-01977-120110

Cleland, E. E., I. Chuine, A. Menzel, H. A. Mooney, and M. D. Schwartz. 2007. Shifting plant phenology in response to global change. Trends in Ecology \& Evolution 22(7):357-365. https://doi. org/10.1016/j.tree.2007.04.003

Clinton, N. E., C. Potter, B. Crabtree, V. Genovese, P. Gross, and P. Gong. 2010. Remote sensing-based time-series analysis of cheatgrass (Bromus tectorum L.) phenology. Journal of Environment Quality 39(3):955-963. https://doi.org/10.2134/ jeq2009.0158

Coppin, P., E. Lambin, I. Jonckheere, and B. Muys. 2002. Digital change detection methods in natural ecosystem monitoring: a review. Pages 3-36 in L. Bruzzone and P. Smits, editors. Analysis of multi-temporal remote sensing images. World Scientific, Singapore. https://doi.org/10.1142/97898127772490001

Daw, T. M. 2010. Shifting baselines and memory illusions: what should we worry about when inferring trends from resource user interviews? Animal Conservation 13(6):534-535. https://doi. org/10.1111/j.1469-1795.2010.00418.x

De Deyn, G. B., J. H. C. Cornelissen, and R. D. Bardgett. 2008. Plant functional traits and soil carbon sequestration in contrasting biomes. Ecology Letters 11(5):516-531. https://doi. org/10.1111/j.1461-0248.2008.01164.x

de Mûelenaere, S., A. Frank1, M. Haile, J. Poesen, J. Deckers, N. Munro, S. Veraverbeke, and J. Nyssen. 2014. Historical landscape photographs for calibration of Landsat land use/cover in the northern Ethiopian highlands. Land Degradation \& Development 25(4):319-335. https://doi.org/10.1002/ldr.2142

De'ath, G., and K. E. Fabricius. 2000. Classification and regression trees: a powerful yet simple technique for ecological data analysis. Ecology 81(11):3178-3192. https://doi.org/10.1890/0012-9658 (2000)081[3178:CARTAP]2.0.CO;2

DeFries, R. S., E. C. Ellis, F. S. Chapin III, P. A. Matson, B. L. Turner II, A. Agrawal, P. J. Crutzen, C. Field, P. Gleick, P. M. Kareiva, E. Lambin, D. Liverman, E. Ostrom, P. A. Sanchez, and J. Syvitski. 2012. Planetary opportunities: a social contract for global change science to contribute to a sustainable future BioScience 62(6):603-606. https://doi.org/10.1525/bio.2012.62.6.11 
Díaz, S., S. Demissew, C. Joly, W. M. Lonsdale, and A. Larigauderie. 2015. A Rosetta Stone for nature's benefits to people. PLOS Biology 13(1):e1002040. https://doi.org/10.1371/ journal.pbio. 1002040

Dietz, T., E. Ostrom, and P. C. Stern. 2003. The struggle to govern the commons. Science 302(5652):1907-1912. https://doi. org/10.1126/science.1091015

Dinku, T., P. Ceccato, and S. J. Connor. 2011. Challenges of satellite rainfall estimation over mountainous and arid parts of east Africa. International Journal of Remote Sensing 32 (21):5965-5979. https://doi.org/10.1080/01431161.2010.499381

Dubeau, P., D. J. King, D. G. Unbushe, and L.-M. Rebelo. 2017. Mapping the Dabus Wetlands, Ethiopia, using random forest classification of Landsat, PALSAR and Topographic Data. Remote Sensing 9(10):1056. https://doi.org/10.3390/rs9101056

Dudley, N. 2008. Guidelines for applying protected area management categories. International Union for Conservation of Nature, Gland, Switzerland. https://doi.org/10.2305/IUCN. CH.2008.PAPS.2.en

Eddy, I. M. S., S. E. Gergel, N. C. Coops, G. M. Henebry, J. Levine, H. Zerriffi, and E. Shibkov. 2017. Integrating remote sensing and local ecological knowledge to monitor rangeland dynamics. Ecological Indicators 82:106-116. https://doi.org/10.1016/j. ecolind.2017.06.033

Ehrlich, P. R., and A. H. Ehrlich. 1981. Extinction: the causes and consequences of the disappearance of species. Ballantine Books, New York, New York, USA.

Étienne, M. 2013. Companion modelling: a participatory approach to support sustainable development. Springer, Dordrecht, The Netherlands.

Fashing, P. J., N. Nguyen, V. V. Venkataraman, and J. T. Kerby. 2014. Gelada feeding ecology in an intact ecosystem at Guassa, Ethiopia: variability over time and implications for theropith and hominin dietary evolution. American Journal of Physical Anthropology 155(1):1-16. https://doi.org/10.1002/ajpa.22559

Fernandez-Gimenez, M. E. 2000. The role of Mongolian nomadic pastoralists' ecological knowledge in rangeland management. Ecological Applications 10(5):1318-1326. https:// doi.org/10.1890/1051-0761(2000)010[1318:TROMNP]2.0.CO;2

Fernandez-Gimenez, M. E., H. P. Huntington, and K. J. Frost. 2006. Integration or co-optation? Traditional knowledge and science in the Alaska Beluga Whale Committee. Environmental Conservation 33(4):306-315. https://doi.org/10.1017/S0376892906003420

Fischer, A., D. T. Wakjira, Y. T. Weldesemaet, and Z. T. Ashenafi. 2014. On the interplay of actors in the co-management of natural resources - a dynamic perspective. World Development 64:158-168. https://doi.org/10.1016/j.worlddev.2014.05.026

Folke, C. 2004. Traditional knowledge in social-ecological systems. Ecology and Society 9(3):7. https://doi.org/10.5751/ ES-01237-090307

Funk, C., P. Peterson, M. Landsfeld, D. Pedreros, J. Verdin, S. Shukla, G. Husak, J. Rowland, L. Harrison, A. Hoell, and J. Michaelsen. 2015. The climate hazards infrared precipitation with stations-a new environmental record for monitoring extremes. Scientific Data 2:150066. https://doi.org/10.1038/sdata.2015.66

Gagnon, C. A., and D. Berteaux. 2009. Integrating traditional ecological knowledge and ecological science: a question of scale. Ecology and Society 14(2):19. https://doi.org/10.5751/ES-02923-140219

Gearheard, S., M. Pocernich, R. Stewart, J. Sanguya, and H. P. Huntington. 2010. Linking Inuit knowledge and meteorological station observations to understand changing wind patterns at Clyde River, Nunavut. Climatic Change 100(2):267-294. https:// doi.org/10.1007/s10584-009-9587-1

Gibbs, A. 2012. Focus groups and group interviews. Pages 186-192 in J. Arthur, M. Waring, R. Coe, and L. V. Hedges, editors. Research methods and methodologies in education. SAGE, London, UK.

Herrmann, S. M., I. Sall, and O. Sy. 2014. People and pixels in the Sahel: a study linking coarse-resolution remote sensing observations to land users' perceptions of their changing environment in Senegal. Ecology and Society 19(3):29. https://doi. org/10.5751/ES-06710-190329

Huntington, H. P. 2000. Using traditional ecological knowledge in science: methods and applications. Ecological Applications 10 (5):1270-1274. https://doi.org/10.1890/1051-0761(2000)010[1270: UTEKIS]2.0.CO;2

Huntington, H. P., R. S. Suydam, and D. H. Rosenberg. 2004. Traditional knowledge and satellite tracking as complementary approaches to ecological understanding. Environmental Conservation 31(3):177-180. https://doi.org/10.1017/S0376892904001559

Isager, L., and N. H. Broge. 2007. Combining remote sensing and anthropology to trace historical land-use changes and facilitate better landscape management in a sub-watershed in North Thailand. Landscape Research 32(2):147-169. https://doi. org/10.1080/01426390701231515

Jacob, M., L. Romeyns, A. Frankl, T. Asfaha, H. Beeckman, and J. Nyssen. 2016. Land use and cover dynamics since 1964 in the Afro-Alpine vegetation belt: Lib Amba Mountain in north Ethiopia. Land Degradation \& Development 27(3):641-653. https://doi.org/10.1002/ldr.2396

Jamsranjav, C., M. E. Fernández-Giménez, R. S. Reid, and B. Adya. 2019. Opportunities to integrate herders' indicators into formal rangeland monitoring: an example from Mongolia. Ecological Applications 29(5):e01899. https://doi.org/10.1002/ eap.1899

Jasanoff, S. 2004. States of knowledge: the co-production of science and the social order. Routledge, London, UK. https://doi. org/10.4324/9780203413845

Kauth, R. J., and G. S. Thomas. 1976. The Tasselled Cap - a graphic description of the spectral-temporal development of agricultural crops as seen by LANDSAT. LARS Symposia. Paper 159.

Kennedy, R. E., S. Andréfouët, W. B. Cohen, C. Gómez, P. Griffiths, M. Hais, S. P. Healey, E. H. Helmer, P. Hostert, M. B. Lyons, G. W. Meigs, D. Pflugmacher, S. R. Phinn, S. L. Powell, P. Scarth, S. Sen, T. A. Schroeder, A. Schneider, R. Sonnenschein, J. E. Vogelmann, M. A. Wulder, and Z. Zhu. 2014. Bringing an 
ecological view of change to Landsat-based remote sensing. Frontiers in Ecology and the Environment 12(6):339-346. https:// doi.org/10.1890/130066

Key, C. H., and N. C. Benson. 2006. Landscape assessment: sampling and analysis methods. General Technical Report RMRSGTR-164-CD. U.S. Forest Service, Rocky Mountain Research Station, Ogden, Utah, USA.

Klain, S. C., and K. M. A. Chan. 2012. Navigating coastal values: participatory mapping of ecosystem services for spatial planning. Ecological Economics 82:104-113. https://doi.org/10.1016/j. ecolecon.2012.07.008

Klein, J. A., K. A. Hopping, E. T. Yeh, Y. Nyima, R. B. Boone, and K. A. Galvin. 2014. Unexpected climate impacts on the Tibetan Plateau: local and scientific knowledge in findings of delayed summer. Global Environmental Change 28:141-152. https://doi.org/10.1016/j.gloenvcha.2014.03.007

Laidler, G. J. 2006. Inuit and scientific perspectives on the relationship between sea ice and climate change: the ideal complement? Climatic Change 78(2-4):407-444. https://doi. org/10.1007/s10584-006-9064-Z

Lambin, E. F., and P. Meyfroidt. 2010. Land use transitions: socio-ecological feedback versus socio-economic change. Land Use Policy 27(2):108-118. https://doi.org/10.1016/j.

landusepol.2009.09.003

Lambin, E. F., B. L. Turner, H. J. Geist, S. B. Agbola, A. Angelsen, J. W. Bruce, O. T. Coomes, R. Dirzo, G. Fischer, C. Folke, P. S. George, K. Homewood, J. Imbernon, R. Leemans, X. Li, E. F. Moran, M. Mortimore, P. S. Ramakrishnan, J. F. Richards, H. Skånes, W. Steffen, G. D. Stone, U. Svedin, T. A. Veldkamp, C. Vogel, and J. Xu. 2001. The causes of land-use and land-cover change: moving beyond the myths. Global Environmental Change 11(4):261-269. https://doi.org/10.1016/S0959-3780(01)00007-3

Lanckriet, S., B. Derudder, J. Naudts, H. Bauer, J. Deckers, M. Haile, and J. Nyssen. 2015. A political ecology perspective of land degradation in the north Ethiopian highlands. Land Degradation \& Development 26(5):521-530. https://doi.org/10.1002/ldr.2278

Latulippe, N. 2015. Situating the work: a typology of traditional knowledge literature. AlterNative: An International Journal of Indigenous Peoples 11(2):118-131. https://doi.org/10.1177/117718011501100203

Levine, J., M. Muthukrishna, K. M. A. Chan, and T. Satterfield. 2017. Sea otters, social justice, and ecosystem-service perceptions in Clayoquot Sound, Canada. Conservation Biology 31 (2):343-352. https://doi.org/10.1111/cobi.12795

Longhurst, R. 2003. Semi-structured interviews and focus groups. Pages 143-156 in N. Clifford, M. Cope, T. Gillespie, and S. French, editors. Key methods in geography. SAGE, London, UK.

Luizza, M. W., T. Wakie, P. H. Evangelista, and C. S. Jarnevich. 2016. Integrating local pastoral knowledge, participatory mapping, and species distribution modeling for risk assessment of invasive rubber vine (Cryptostegia grandiflora) in Ethiopia's Afar region. Ecology and Society 21(1):22. https://doi. org/10.5751/es-07988-210122

Masek, J. G., E. F. Vermote, N. E. Saleous, R. Wolfe, F. G. Hall, K. F. Huemmrich, Feng Gao, J. Kutler, and Teng-Kui Lim. 2006.
A Landsat surface reflectance dataset for North America, 1990-2000. IEEE Geoscience and Remote Sensing Letters 3 (1):68-72. https://doi.org/10.1109/lgrs.2005.857030

McLain, R. J., and R. G. Lee. 1996. Adaptive management: promises and pitfalls. Environmental Management 20(4):437-448. https://doi.org/10.1007/BF01474647

Menz Gera Woreda Administration (MGWA). 2016. Report on participation in safety net program by kebele. MGWA, Ethiopia.

Moller, H., F. Berkes, P. O. Lyver, and M. Kislalioglu. 2004. Combining science and traditional ecological knowledge: monitoring populations for co-management. Ecology and Society 9(3):2. https://doi.org/10.5751/ES-00675-090302

Nadasdy, P. 1999. The politics of TEK: power and the "integration" of knowledge. Arctic Anthropology 36(1/2):1-18.

Naidoo, R., and K. Hill. 2006. Emergence of indigenous vegetation classifications through integration of traditional ecological knowledge and remote sensing analyses. Environmental Management 38(3):377-387. https://doi.org/10.1007/s00267-004-0338-9

NASA/METI/AIST/Japan Spacesystems and U.S./Japan ASTER Science Team. 2009. ASTER Global Digital Elevation Model. NASA EOSDIS Land Processes DAAC. https://doi.org/10.5067/ ASTER/ASTGTM.002

Nazarea, V. D. 2006. Local knowledge and memory in biodiversity conservation. Annual Review of Anthropology 35 (1):317-335. https://doi.org/10.1146/annurev.anthro.35.081705.123252

Nichols, T., F. Berkes, D. Jolly, N. B. Snow, and the community of Sachs Harbour. 2004. Climate change and sea ice: local observations from the Canadian Western Arctic. Arctic 57 (1):68-79. https://doi.org/10.14430/arctic484

Nyssen, J., J. Poesen, M. Veyret-Picot, J. Moeyersons, M. Haile, J. Deckers, J. Dewit, J. Naudts, K. Teka, and G. Govers. 2006. Assessment of gully erosion rates through interviews and measurements: a case study from northern Ethiopia. Earth Surface Processes and Landforms 31(2):167-185. https://doi. org/10.1002/esp.1317

Ostrom, E. 2007. A diagnostic approach for going beyond panaceas. Proceedings of the national Academy of Sciences 104 (39):15181-15187. https://doi.org/10.1073/pnas.0702288104

Pandeya, B., W. Buytaert, Z. Zulkafli, T. Karpouzoglou, F. Mao, and D. M. Hannah. 2016. A comparative analysis of ecosystem services valuation approaches for application at the local scale and in data scarce regions. Ecosystem Services 22:250-259. https:// doi.org/10.1016/j.ecoser.2016.10.015

Pauly, D. 1995. Anecdotes and the shifting baseline syndrome of fisheries. Trends in Ecology \& Evolution 10(10):430. https://doi. org/10.1016/S0169-5347(00)89171-5

Pepin, N., R. S. Bradley, H. F. Diaz, M. Baraer, E. B. Caceres, N. Forsythe, H. Fowler, G. Greenwood, M. Z. Hashmi, X. D. Liu, J. R. Miller, L. Ning, A. Ohmura, E. Palazzi, I. Rangwala, W. Schöner, I. Severskiy, M. Shahgedanova, M. B. Wang, S. N. Williamson, and D. Q. Yang. 2015. Elevation-dependent warming in mountain regions of the world. Nature Climate Change 5 (5):424-430. https://doi.org/10.1038/nclimate2563 
Persha, L., A. Agrawal, and A. Chhatre. 2011. Social and ecological synergy: local rulemaking, forest livelihoods, and biodiversity conservation. Science 331(6024):1606-1608. https:// doi.org/10.1126/science.1199343

Prado, H. M., R. S. S. Murrieta, C. Adams, and E. S. Brondizio. 2013. Complementary viewpoints: scientific and local knowledge of ungulates in the Brazilian Atlantic Forest. Journal of Ethnobiology 33(2):180-202. https://doi.org/10.2993/0278-0771-33.2.180

R Core Development Team. 2019. R: A language and environment for statistical computing. R Foundation for Statistical Computing, Vienna, Austria.

Raudsepp-Hearne, C., G. D. Peterson, and E. M. Bennett. 2010. Ecosystem service bundles for analyzing tradeoffs in diverse landscapes. Proceedings of the National Academy of Sciences 107 (11):5242-5247. https://doi.org/10.1073/pnas.0907284107

Reed, M. S., I. Fazey, L. C. Stringer, C. M. Raymond, M. AkhtarSchuster, G. Begni, H. Bigas, S. Brehm, J. Briggs, R. Bryce, S. Buckmaster, R. Chanda, J. Davies, E. Diez, W. Essahli, A. Evely, N. Geeson, I. Hartmann, J. Holden, K. Hubacek, A. A. R. Ioris, B. Kruger, P. Laureano, J. Phillipson, C. Prell, C. H. Quinn, A. D. Reeves, M. Seely, R. Thomas, M. J. van der W. T. Bosch, P. Vergunst, and L. Wagner. 2013. Knowledge management for land degradation monitoring and assessment: an analysis of contemporary thinking. Land Degradation \& Development 24 (4):307-322. https://doi.org/10.1002/1dr.1124

Reid, W., F. Berkes, T. D. C. Wilbanks. 2006. Bridging scales and knowledge systems. Millennium Ecosystem Assessment and Island Press, Washington, D.C., USA.

Rishmawi, K., S. D. Prince, and Y. Xue. 2016. Vegetation responses to climate variability in the northern arid to sub-humid zones of sub-Saharan Africa. Remote Sensing 8(11):910. https:// doi.org/10.3390/rs8110910

Robbins, P., and T. Maddock. 2000. Interrogating land cover categories: metaphor and method in remote sensing. Cartography and Geographic Information Science 27(4):295-309. https://doi. org/10.1559/152304000783547740

Rockström, J., W. Steffen, K. Noone, Å. Persson, F. S. Chapin, E. F. Lambin, T. M. Lenton, M. Scheffer, C. Folke, H. J. Schellnhuber, B. Nykvist, C. A. de Wit, T. Hughes, S. van der Leeuw, H. Rodhe, S. Sörlin, P. K. Snyder, R. Costanza, U. Svedin, M. Falkenmark, L. Karlberg, R. W. Corell, V. J. Fabry, J. Hansen, B. Walker, D. Liverman, K. Richardson, P. Crutzen, and J. A. Foley. 2009. A safe operating space for humanity. Nature 461 (7263):472-475. https://doi.org/10.1038/461472a

Rodriguez-Galiano, V. F., B. Ghimire, J. Rogan, M. Chica-Olmo, and J. P. Rigol-Sanchez. 2012. An assessment of the effectiveness of a random forest classifier for land-cover classification. ISPRS Journal of Photogrammetry and Remote Sensing 67:93-104. https://doi.org/10.1016/j.isprsjprs.2011.11.002

Ruiz-Mallén, I., and E. Corbera. 2013. Community-based conservation and traditional ecological knowledge: implications for social-ecological resilience. Ecology and Society 18(4):12. https://doi.org/10.5751/ES-05867-180412

Sankaran, M., N. P. Hanan, R. J. Scholes, J. Ratnam, D. J. Augustine, B. S. Cade, J. Gignoux, S. I. Higgins, X. Le Roux, F.
Ludwig, J. Ardo, F. Banyikwa, A. Bronn, G. Bucini, K. K. Caylor, M. B. Coughenour, A. Diouf, W. Ekaya, C. J. Feral, E. C. February, P. G. H. Frost, P. Hiernaux, H. Hrabar, K. L. Metzger, H. H. T. Prins, S. Ringrose, W. Sea, J. Tews, J. Worden, and N. Zambatis. 2005. Determinants of woody cover in African savannas. Nature 438(7069):846-849. https://doi.org/10.1038/ nature 04070

Shirk, J. L., H. L. Ballard, C. C. Wilderman, T. Phillips, A. Wiggins, R. Jordan, E. McCallie, M. Minarchek, B. V. Lewenstein, M. E. Krasny, and R. Bonney. 2012. Public participation in scientific research: a framework for deliberate design. Ecology and Society 17(2):29. https://doi.org/10.5751/ ES-04705-170229

Smith, V., C. Portillo-Quintero, A. Sanchez-Azofeifa, and J. L. Hernandez-Stefanoni. 2019. Assessing the accuracy of detected breaks in Landsat time series as predictors of small scale deforestation in tropical dry forests of Mexico and Costa Rica. Remote Sensing of Environment 221:707-721. https://doi. org/10.1016/j.rse.2018.12.020

Star, S. L. 2010. This is not a boundary object: reflections on the origin of a concept. Science, Technology, \& Human Values 35 (5):601-617. https://doi.org/10.1177/0162243910377624

Star, S. L., and J. R. Griesemer. 1989. Institutional ecology, 'translations' and boundary objects: amateurs and professionals in Berkeley's Museum of Vertebrate Zoology, 1907-39. Social Studies of Science 19(3):387-420. https://doi.org/10.1177/030631289019003001

Steffen, W., Å. Persson, L. Deutsch, J. Zalasiewicz, M. Williams, K. Richardson, C. Crumley, P. Crutzen, C. Folke, L. Gordon, M. Molina, V. Ramanathan, J. Rockström, M. Scheffer, H. J. Schellnhuber, and U. Svedin. 2011. The Anthropocene: from global change to planetary stewardship. Ambio 40:739. https:// doi.org/10.1007/s13280-011-0185-x

Steger, C., S. Hirsch, C. Evers, B. Branoff, M. Petrova, M. NielsenPincus, C. Wardropper, and C. J. Van Riper. 2018. Ecosystem services as boundary objects for transdisciplinary collaboration. Ecological Economics 143:153-160. https://doi.org/10.1016/j. ecolecon.2017.07.016

Tengö, M., E. S. Brondizio, T. Elmqvist, P. Malmer, and M. Spierenburg. 2014. Connecting diverse knowledge systems for enhanced ecosystem governance: the multiple evidence base approach. Ambio 43(5):579-591. https://doi.org/10.1007/ s13280-014-0501-3

Tucker, C.J. 1979. Red and photographic infrared linear combinations for monitoring vegetation. Remote Sensing of Environment 8(2):127-150. https://doi.org/10.1016/0034-4257(79) 90013-0

Turnbull, D. 2000. Masons, tricksters and cartographers: comparative studies in the sociology of scientific and indigenous knowledge. Taylor \& Francis, London, UK. https://doi. org/10.4324/9780203304587

Turner, B. L., E. F. Lambin, and A. Reenberg. 2007. The emergence of land change science for global environmental change and sustainability. Proceedings of the National Academy of Sciences 104(52):20666-20671. https://doi.org/10.1073/ pnas.0704119104 
Turnhout, E., B. Bloomfield, M. Hulme, J. Vogel, and B. Wynne. 2012. Listen to the voices of experience. Nature 488 (7412):454-455. https://doi.org/10.1038/488454a

Vågen, T.-G., L. A. Winowiecki, A. Abegaz, and K. M. Hadgu. 2013. Landsat-based approaches for mapping of land degradation prevalence and soil functional properties in Ethiopia. Remote Sensing of Environment 134:266-275. https://doi. org/10.1016/j.rse.2013.03.006

Verburg, P. H., K. Neumann, and L. Nol. 2011. Challenges in using land use and land cover data for global change studies. Global Change Biology 17(2):974-989. https://doi.org/10.1111/ j.1365-2486.2010.02307.x

Vitousek, P. M., L. L. Loope, and R. Westbrooks. 1996. Biological invasions as global environmental change. American Scientist 84 (5):468.

Vogels, M. F. A., S. M. de Jong, G. Sterk, and E. A. Addink. 2019. Mapping irrigated agriculture in complex landscapes using SPOT6 imagery and object-based image analysis - a case study in the Central Rift Valley, Ethiopia. International Journal of Applied Earth Observation and Geoinformation 75:118-129. https://doi. org/10.1016/j.jag.2018.07.019

Wakie, T. T., M. Laituri, and P. H. Evangelista. 2016. Assessing the distribution and impacts of Prosopis juliflora through participatory approaches. Applied Geography 66:132-143. https:// doi.org/10.1016/j.apgeog.2015.11.017

Welch, C. 2017. Where the world's only grass-eating monkeys thrive. National Geographic, April.

Woodcock, C. E., R. Allen, M. Anderson, A. Belward, R. Bindschadler, W. Cohen, F. Gao, S. N. Goward, D. Helder, E. Helmer, R. Nemani, L. Oreopoulos, J. Schott, P. S. Thenkabail, E. F. Vermote, J. Vogelmann, M. A. Wulder, and R. Wynne. 2008. Free access to Landsat imagery. Science 320(5879):1011. https:// doi.org/10.1126/science.320.5879.1011a

Wulder, M. A., T. R. Loveland, D. P. Roy, C. J. Crawford, J. G. Masek, C. E. Woodcock, R. G. Allen, M. C. Anderson, A. S. Belward, W. B. Cohen, J. Dwyer, A. Erb, F. Gao, P. Griffiths, D. Helder, T. Hermosilla, J. D. Hipple, P. Hostert, M. J. Hughes, J. Huntington, D. M. Johnson, R. Kennedy, A. Kilic, Z. Li, L. Lymburner, J. McCorkel, N. Pahlevan, T. A. Scambos, C. Schaaf, J. R. Schott, Y. Sheng, J. Storey, E. Vermote, J. Vogelmann, J. C. White, R. H. Wynne, and Z. Zhu. 2019. Current status of Landsat program, science, and applications. Remote Sensing of Environment 225:127-147. https://doi.org/10.1016/j.rse.2019.02.015

Young, N. E., R. S. Anderson, S. M. Chignell, A. G. Vorster, R. Lawrence, and P. H. Evangelista. 2017. A survival guide to Landsat preprocessing. Ecology 98(4):920-932. https://doi. org/10.1002/ecy.1730

Zhu, Z., and C. E. Woodcock. 2012. Object-based cloud and cloud shadow detection in Landsat imagery. Remote Sensing of Environment 118:83-94. https://doi.org/10.1016/j.rse.2011.10.028 
Appendix 1

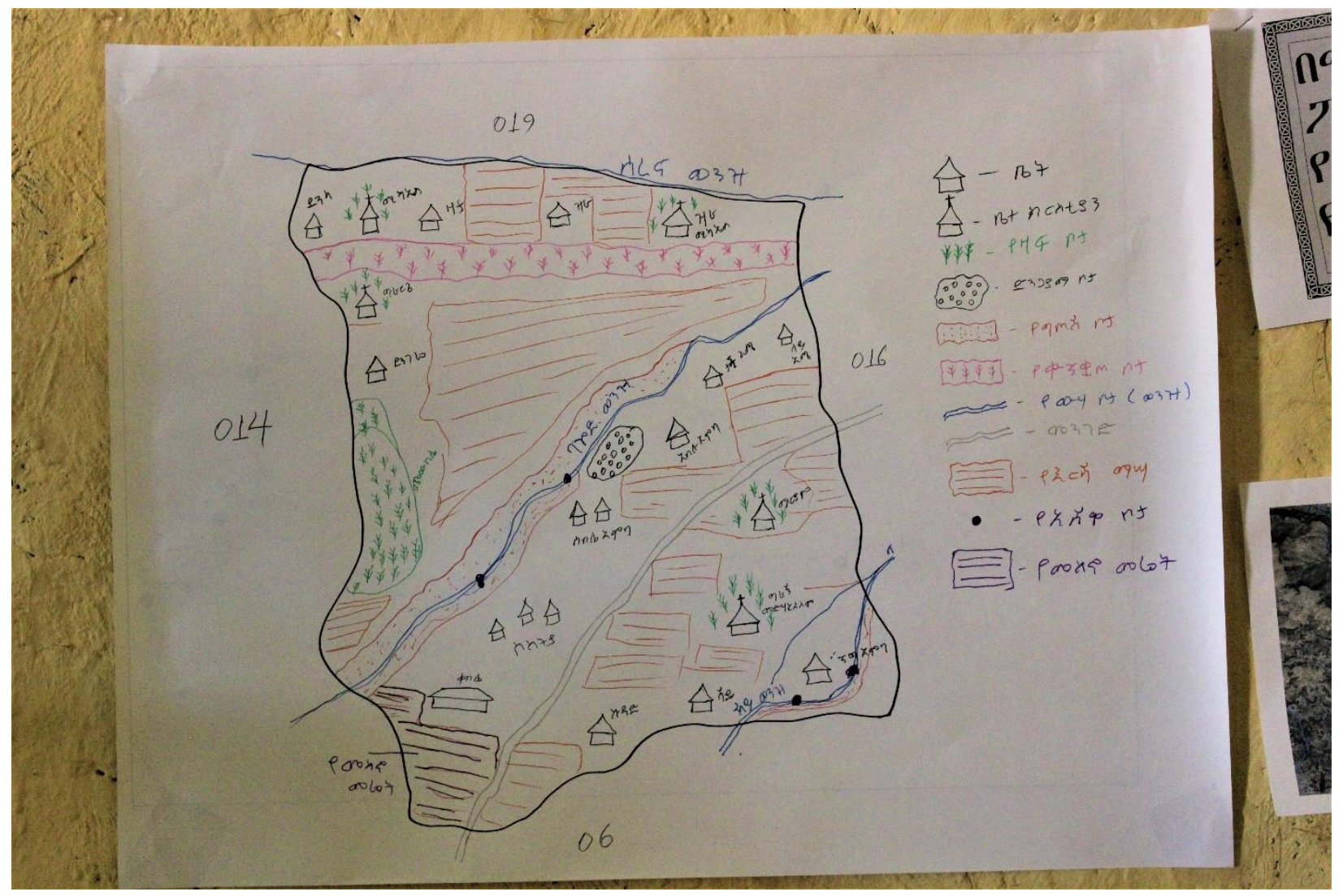

Fig. A1.1. Participatory map drawn by residents of kebele 15 (Gragne). 


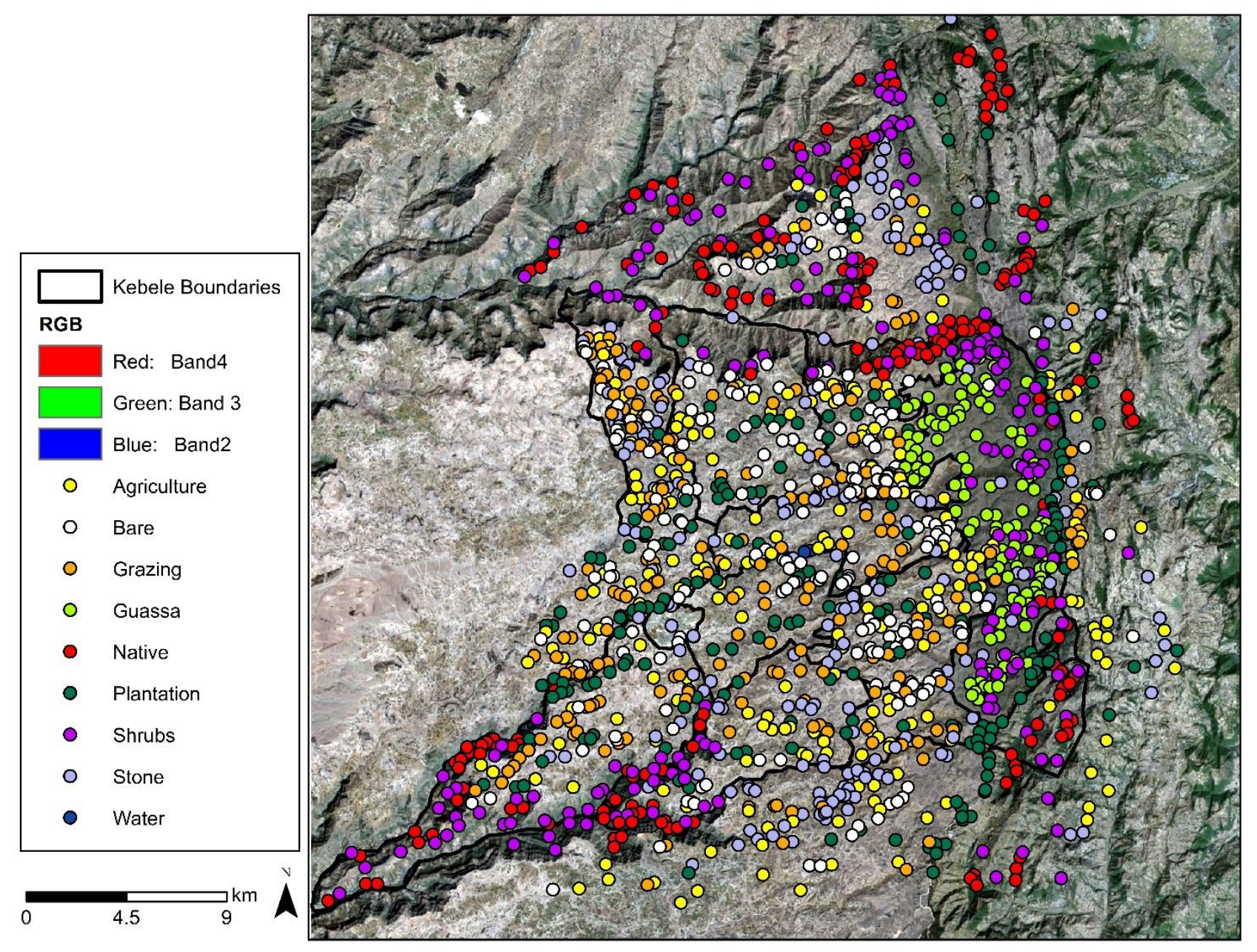

Fig. A1.2. Map displaying the distribution of training points used for each land class in the random forest classifier. 


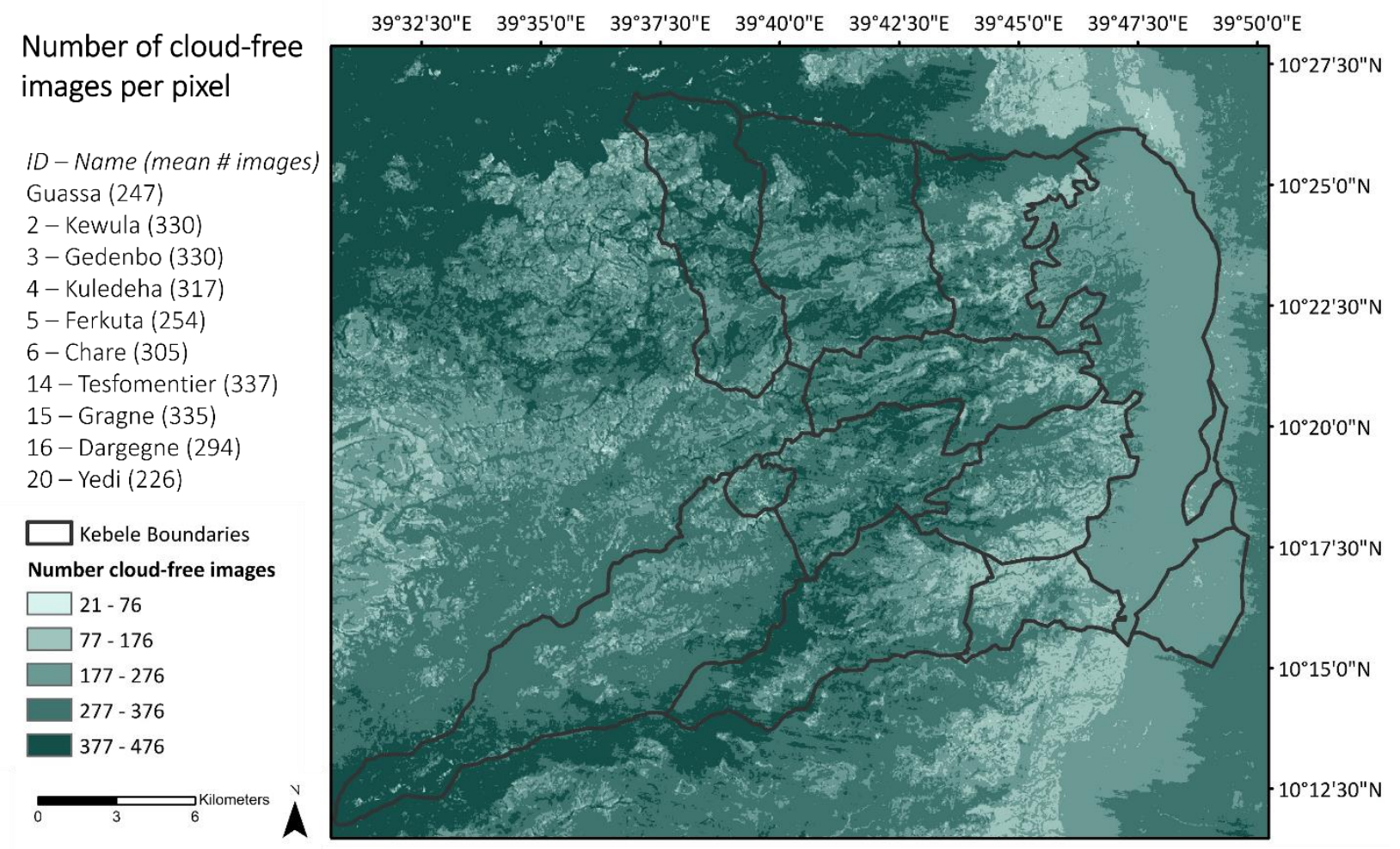

Fig. A1.3. The number of cloud-free images per pixel across the study area. 

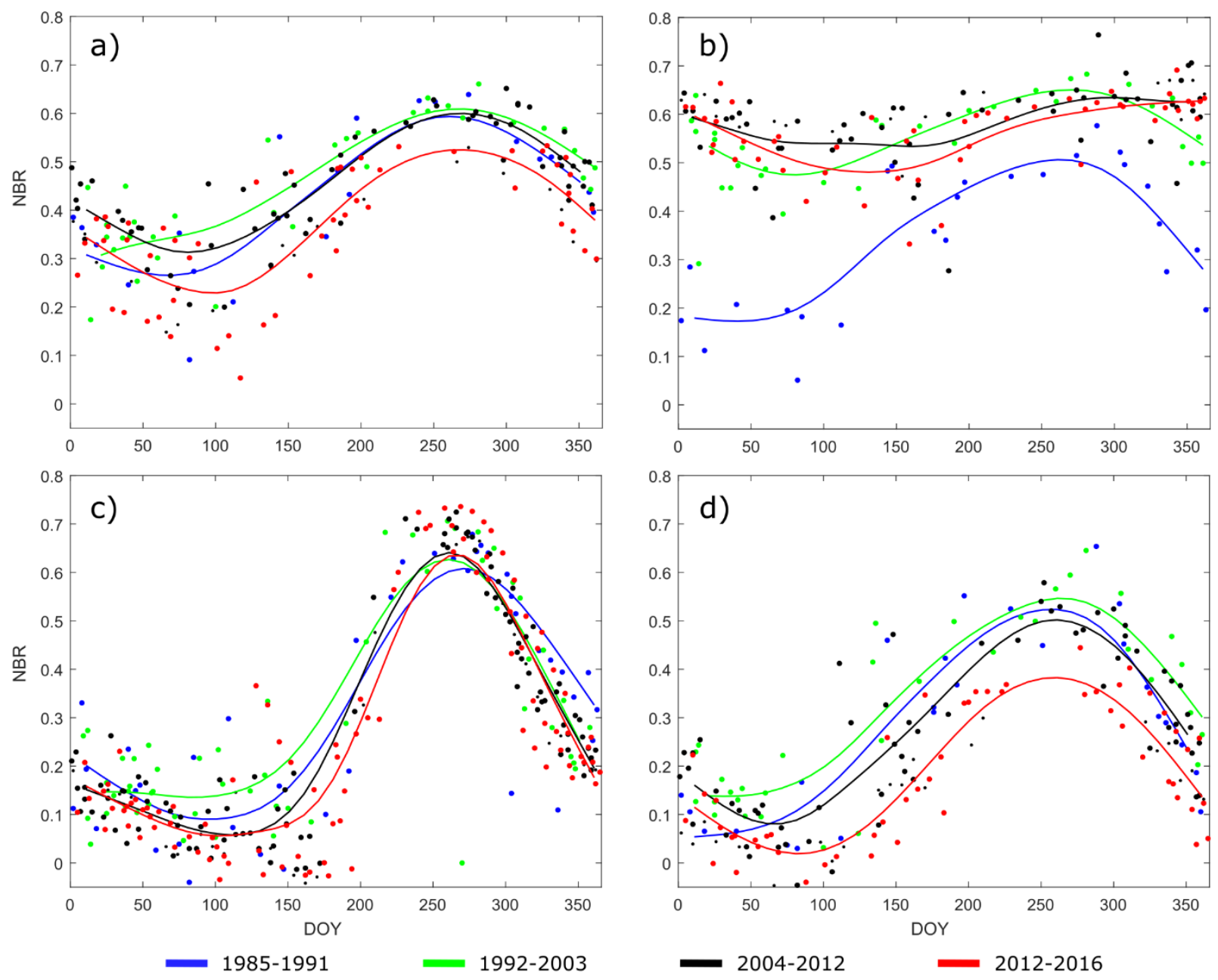

Fig. A1.4. Spline interpolation results for four pixels in our study area showing changes across political and management periods in a) shrublands, b) plantation forest, c) grazing land, and d) protected grassland. For example, the blue line (Derg period) demonstrates the seasonal pattern of the vegetation prior to the establishment of a plantation forest, while the green, black, and red lines are showing the seasonal pattern of the plantation forest in subsequent periods, which is far less variable. There are 70 images in the Derg period ( 44 with $<50 \%$ cloud cover), 148 images in the Transition period ( 87 with $<50 \%$ cloud cover), 147 images in the NGO period ( 86 with $<50 \%$ cloud cover), and 232 in the Co-management period (135 with <50\% cloud cover). 


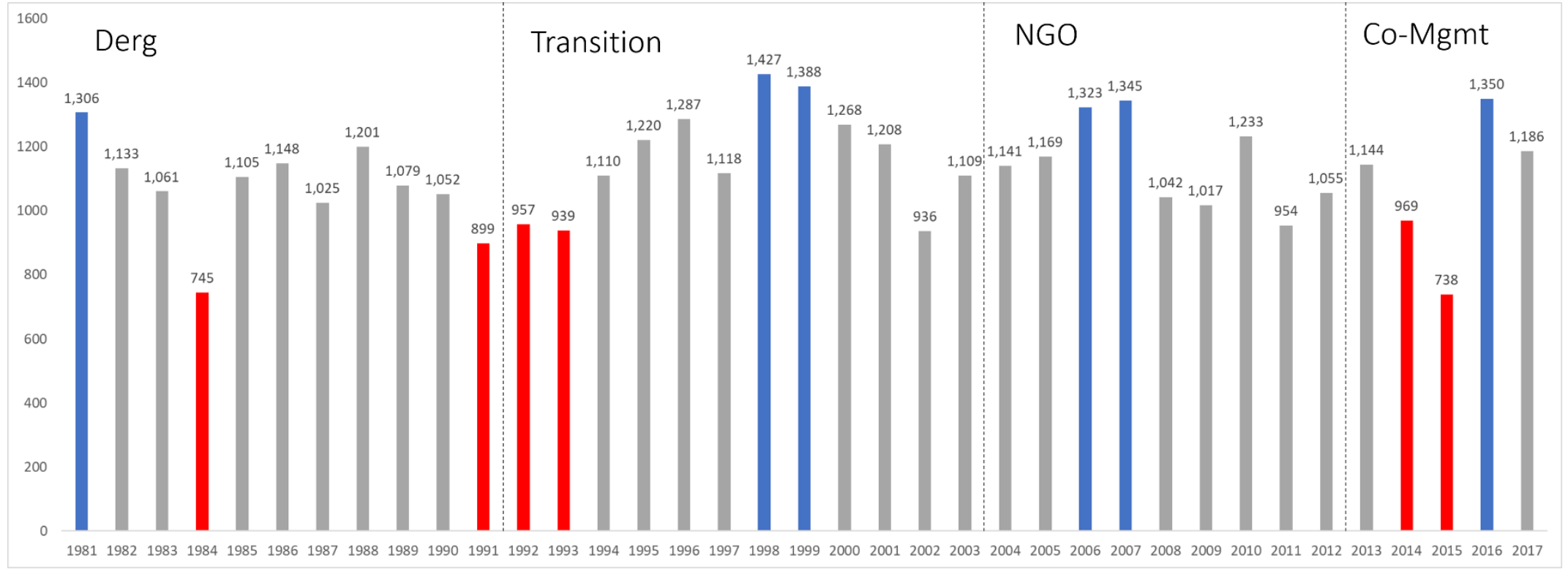

Fig. A1.5. Total annual precipitation (from CHIRPS). Wet years (in blue, precip $>1300 \mathrm{~mm}$ ) and dry years (in red, precip $<1000$ $\mathrm{mm}$ ) were fairly evenly distributed throughout the study period except for the NGO period. 


\begin{tabular}{|c|c|c|c|c|c|c|c|c|c|c|c|c|}
\hline \multicolumn{13}{|c|}{ Actual Class } \\
\hline \multirow{12}{*}{ 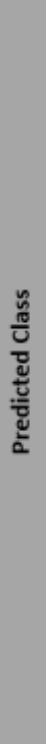 } & & 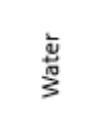 & 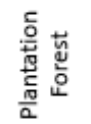 & 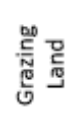 & 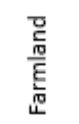 & $\begin{array}{l}\text { 气̆ } \\
\text { 今ั }\end{array}$ & 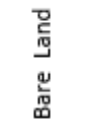 & 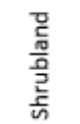 & $\begin{array}{l}\text { 突莸 } \\
\text { 范 }\end{array}$ & 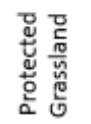 & Total & $\begin{array}{l}\text { User's } \\
\text { Accuracy }\end{array}$ \\
\hline & Water & 2 & 0 & 0 & 0 & 0 & 0 & 0 & 0 & 0 & 2 & $100.0 \%$ \\
\hline & $\begin{array}{c}\text { Plantation } \\
\text { Forest }\end{array}$ & 0 & 201 & 0 & 0 & 0 & 0 & 3 & 6 & 0 & 210 & $95.7 \%$ \\
\hline & $\begin{array}{c}\text { Grazing } \\
\text { Land }\end{array}$ & 0 & 0 & 178 & 6 & 6 & 13 & 0 & 0 & 7 & 210 & $84.8 \%$ \\
\hline & Farmland & 0 & 0 & 5 & 205 & 11 & 3 & 1 & 0 & 0 & 225 & $80.4 \%$ \\
\hline & Stone & 0 & 0 & 2 & 16 & 179 & 23 & 3 & 0 & 2 & 225 & $79.6 \%$ \\
\hline & Bare Land & 0 & 0 & 13 & 2 & 14 & 181 & 0 & 0 & 0 & 210 & $86.2 \%$ \\
\hline & Shrubland & 0 & 3 & 0 & 0 & 2 & 0 & 173 & 30 & 2 & 210 & $82.4 \%$ \\
\hline & $\begin{array}{l}\text { Native } \\
\text { Forest }\end{array}$ & 0 & 3 & 0 & 0 & 0 & 0 & 24 & 183 & 0 & 210 & $87.1 \%$ \\
\hline & $\begin{array}{l}\text { Protected } \\
\text { Grassland }\end{array}$ & 0 & 0 & 4 & 0 & 3 & 0 & 3 & 0 & 110 & 120 & $91.7 \%$ \\
\hline & Total & 2 & 207 & 202 & 229 & 215 & 220 & 207 & 219 & 121 & 1622 & \\
\hline & $\begin{array}{l}\text { Producer's } \\
\text { Accuracy }\end{array}$ & $100.0 \%$ & $97.1 \%$ & $88.1 \%$ & $89.5 \%$ & $83.3 \%$ & $82.3 \%$ & $83.6 \%$ & $83.6 \%$ & $90.9 \%$ & & \\
\hline
\end{tabular}

Table A1.1. The confusion matrix for the supervised classification demonstrates the ability of the model to correctly classify a set of training points for each land class using a cross-validation approach. The kappa value for this classification was 0.85 . 


\begin{tabular}{|c|c|c|c|c|c|c|c|c|c|c|}
\hline & 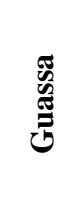 & $\underset{\mathscr{J}}{\stackrel{\Xi}{U}}$ & 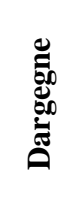 & 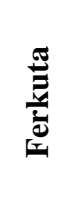 & $\frac{8}{\tilde{E}}$ & 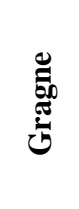 & $\underset{v}{3}$ & 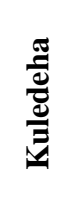 & 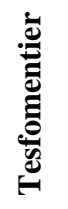 & : \\
\hline Farmland & 1.3 & 16.2 & 15.8 & 19.3 & 17.4 & 25.8 & 21.6 & 19.4 & 15 & 9.4 \\
\hline Stone & 3.2 & 9.4 & 6.7 & 5.9 & 7.1 & 10.2 & 9.5 & 8.1 & 6.7 & 2.3 \\
\hline Shrubland & 21.8 & 0.1 & 3.7 & 1.6 & 0.1 & 7.2 & 17.2 & 5.7 & 4.9 & 6.9 \\
\hline $\begin{array}{l}\text { Protected } \\
\text { Grassland }\end{array}$ & 45.5 & 0.4 & 0.6 & 1.3 & 0 & 0 & 0 & 0.1 & 0 & 0.8 \\
\hline $\begin{array}{c}\text { Grazing } \\
\text { Land }\end{array}$ & 2 & 2.4 & 2.5 & 4.1 & 1.8 & 3.9 & 10.4 & 4.5 & 3.8 & 4.3 \\
\hline Bare Land & 0 & 2.1 & 2.5 & 2 & 2.2 & 5 & 8.8 & 3.3 & 6.3 & 0.8 \\
\hline $\begin{array}{l}\text { Native } \\
\text { Forest }\end{array}$ & 1.7 & 0 & 2.4 & 0.1 & 0 & 0.7 & 4.5 & 2.8 & 0.6 & 3.1 \\
\hline $\begin{array}{c}\text { Plantation } \\
\text { Forest }\end{array}$ & 2.7 & 0.4 & 0.3 & 1.1 & 0.8 & 0.8 & 1.7 & 0.5 & 0.4 & 0.4 \\
\hline Urban & 0 & 0 & 0.2 & 0.1 & 0 & 0 & 0 & 0 & 0 & 0.1 \\
\hline Water & 0 & 0.04 & 0 & 0 & 0.04 & 0 & 0 & 0 & 0 & 0 \\
\hline
\end{tabular}

\begin{tabular}{|c|c|c|c|c|c|c|c|c|c|c|}
\hline & 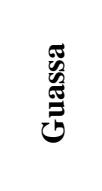 & 竎 & 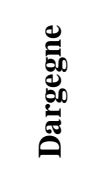 & 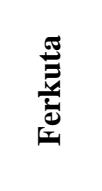 & $\frac{8}{\tilde{E}}$ & שֶ. & $\underset{y}{3}$ & 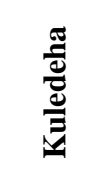 & 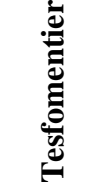 & : \\
\hline Farmland & $1.7 \%$ & $52.2 \%$ & $45.5 \%$ & $54.4 \%$ & $59.1 \%$ & $48.1 \%$ & $29.3 \%$ & $43.7 \%$ & $39.8 \%$ & $33.5 \%$ \\
\hline Stone & $4.1 \%$ & $30.3 \%$ & $19.3 \%$ & $16.6 \%$ & $24.1 \%$ & $19.0 \%$ & $12.9 \%$ & $18.2 \%$ & $17.8 \%$ & $8.2 \%$ \\
\hline Shrubland & $27.9 \%$ & $0.3 \%$ & $10.7 \%$ & $4.5 \%$ & $0.3 \%$ & $13.4 \%$ & $23.3 \%$ & $12.8 \%$ & $13.0 \%$ & $24.6 \%$ \\
\hline $\begin{array}{l}\text { Protected } \\
\text { Grassland }\end{array}$ & $58.2 \%$ & $1.3 \%$ & $1.7 \%$ & $3.7 \%$ & $0.0 \%$ & $0.0 \%$ & $0.0 \%$ & $0.2 \%$ & $0.0 \%$ & $2.8 \%$ \\
\hline $\begin{array}{c}\text { Grazing } \\
\text { Land }\end{array}$ & $2.6 \%$ & $7.7 \%$ & $7.2 \%$ & $11.5 \%$ & $6.1 \%$ & $7.3 \%$ & $14.1 \%$ & $10.1 \%$ & $10.1 \%$ & $15.3 \%$ \\
\hline Bare Land & $0.0 \%$ & $6.8 \%$ & $7.2 \%$ & $5.6 \%$ & $7.5 \%$ & $9.3 \%$ & $11.9 \%$ & $7.4 \%$ & $16.7 \%$ & $2.8 \%$ \\
\hline $\begin{array}{l}\text { Native } \\
\text { Forest } \\
\end{array}$ & $2.2 \%$ & $0.0 \%$ & $6.9 \%$ & $0.3 \%$ & $0.0 \%$ & $1.3 \%$ & $6.1 \%$ & $6.3 \%$ & $1.6 \%$ & $11.0 \%$ \\
\hline $\begin{array}{c}\text { Plantation } \\
\text { Forest }\end{array}$ & $3.5 \%$ & $1.3 \%$ & $0.9 \%$ & $3.1 \%$ & $2.7 \%$ & $1.5 \%$ & $2.3 \%$ & $1.1 \%$ & $1.1 \%$ & $1.4 \%$ \\
\hline City & $0.0 \%$ & $0.0 \%$ & $0.6 \%$ & $0.3 \%$ & $0.0 \%$ & $0.0 \%$ & $0.0 \%$ & $0.0 \%$ & $0.0 \%$ & $0.4 \%$ \\
\hline Water & $0.0 \%$ & $0.1 \%$ & $0.0 \%$ & $0.0 \%$ & $0.1 \%$ & $0.0 \%$ & $0.0 \%$ & $0.0 \%$ & $0.0 \%$ & $0.0 \%$ \\
\hline
\end{tabular}

Table A1.2. Top panel shows square kilometers of each land class, separated according to kebele and the Guassa area. Bottom panel shows the percent of land area occupied by each land class for each kebele and the Guassa area. 


\begin{tabular}{|c|c|c|c|c|c|c|c|c|c|c|c|}
\hline & NBR & 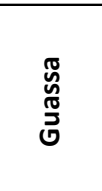 & $\begin{array}{l}\frac{1}{\pi} \\
\frac{\pi}{4}\end{array}$ & 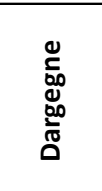 & 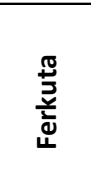 & 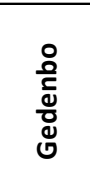 & 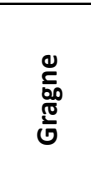 & $\begin{array}{l}\frac{\pi}{7} \\
\bar{d} \\
\underline{0}\end{array}$ & $\begin{array}{l}\frac{\pi}{2} \\
\frac{0}{0} \\
\frac{d}{3} \\
\frac{1}{3}\end{array}$ & 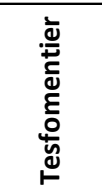 & i் \\
\hline \multirow{5}{*}{ 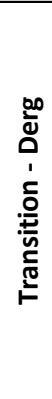 } & $\begin{array}{c}\text { High } \\
\text { Increase }\end{array}$ & $0.1 \%$ & $0.5 \%$ & $0.2 \%$ & $1.2 \%$ & $0.8 \%$ & $0.4 \%$ & $0.5 \%$ & $0.7 \%$ & $0.2 \%$ & $0.5 \%$ \\
\hline & $\begin{array}{c}\text { Low } \\
\text { Increase }\end{array}$ & $69.2 \%$ & $65.7 \%$ & $46.2 \%$ & $72.3 \%$ & $67.6 \%$ & $40.6 \%$ & $70.3 \%$ & $74.0 \%$ & $48.6 \%$ & $50.7 \%$ \\
\hline & $\begin{array}{c}\text { No } \\
\text { Change }\end{array}$ & $30.5 \%$ & $33.2 \%$ & $51.5 \%$ & $25.8 \%$ & $31.1 \%$ & $56.5 \%$ & $28.9 \%$ & $24.8 \%$ & $50.1 \%$ & $47.3 \%$ \\
\hline & $\begin{array}{c}\text { Low } \\
\text { Decrease }\end{array}$ & $0.2 \%$ & $0.7 \%$ & $2.1 \%$ & $0.6 \%$ & $0.5 \%$ & $2.5 \%$ & $0.3 \%$ & $0.6 \%$ & $1.1 \%$ & $1.5 \%$ \\
\hline & $\begin{array}{c}\text { High } \\
\text { Decrease }\end{array}$ & $0.0 \%$ & $0.0 \%$ & $0.0 \%$ & $0.0 \%$ & $0.0 \%$ & $0.0 \%$ & $0.0 \%$ & $0.0 \%$ & $0.0 \%$ & $0.0 \%$ \\
\hline \multirow{5}{*}{ 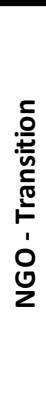 } & $\begin{array}{c}\text { High } \\
\text { Increase }\end{array}$ & $0.0 \%$ & $0.0 \%$ & $0.0 \%$ & $0.0 \%$ & $0.1 \%$ & $0.2 \%$ & $0.0 \%$ & $0.0 \%$ & $0.7 \%$ & $0.0 \%$ \\
\hline & $\begin{array}{c}\text { Low } \\
\text { Increase }\end{array}$ & $0.4 \%$ & $6.4 \%$ & $1.7 \%$ & $2.7 \%$ & $11.5 \%$ & $16.1 \%$ & $4.8 \%$ & $4.4 \%$ & $15.2 \%$ & $2.0 \%$ \\
\hline & $\begin{array}{c}\text { No } \\
\text { Change }\end{array}$ & $66.8 \%$ & $63.7 \%$ & $61.1 \%$ & $59.9 \%$ & $70.3 \%$ & $70.9 \%$ & $61.9 \%$ & $65.8 \%$ & $72.6 \%$ & $71.4 \%$ \\
\hline & $\begin{array}{c}\text { Low } \\
\text { Decrease }\end{array}$ & $32.8 \%$ & $29.8 \%$ & $37.1 \%$ & $37.3 \%$ & $18.1 \%$ & $12.8 \%$ & $33.3 \%$ & $29.8 \%$ & $11.4 \%$ & $26.6 \%$ \\
\hline & $\begin{array}{c}\text { High } \\
\text { Decrease }\end{array}$ & $0.0 \%$ & $0.1 \%$ & $0.1 \%$ & $0.1 \%$ & $0.0 \%$ & $0.0 \%$ & $0.0 \%$ & $0.0 \%$ & $0.0 \%$ & $0.1 \%$ \\
\hline \multirow{5}{*}{ 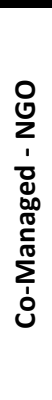 } & $\begin{array}{c}\text { High } \\
\text { Increase }\end{array}$ & $0.0 \%$ & $0.1 \%$ & $0.0 \%$ & $0.0 \%$ & $0.1 \%$ & $0.1 \%$ & $0.0 \%$ & $0.1 \%$ & $0.0 \%$ & $0.0 \%$ \\
\hline & $\begin{array}{c}\text { Low } \\
\text { Increase }\end{array}$ & $2.9 \%$ & $16.9 \%$ & $19.8 \%$ & $10.2 \%$ & $15.3 \%$ & $18.3 \%$ & $9.3 \%$ & $7.7 \%$ & $7.6 \%$ & $5.4 \%$ \\
\hline & $\begin{array}{c}\text { No } \\
\text { Change }\end{array}$ & $73.8 \%$ & $80.5 \%$ & $77.7 \%$ & $81.6 \%$ & $79.5 \%$ & $74.0 \%$ & $83.5 \%$ & $83.7 \%$ & $81.5 \%$ & $82.0 \%$ \\
\hline & $\begin{array}{c}\text { Low } \\
\text { Decrease }\end{array}$ & $23.3 \%$ & $2.5 \%$ & $2.5 \%$ & $8.1 \%$ & $5.1 \%$ & $7.5 \%$ & $7.2 \%$ & $8.5 \%$ & $10.9 \%$ & $12.5 \%$ \\
\hline & $\begin{array}{c}\text { High } \\
\text { Decrease }\end{array}$ & $0.0 \%$ & $0.0 \%$ & $0.0 \%$ & $0.1 \%$ & $0.0 \%$ & $0.0 \%$ & $0.0 \%$ & $0.0 \%$ & $0.0 \%$ & $0.1 \%$ \\
\hline
\end{tabular}

Table A1.3. The percent of land area and direction of vegetation change (from NBR values) for each kebele and the Guassa area across each period of political and management history (wet season). 


\begin{tabular}{|c|c|c|c|c|c|c|c|c|c|c|c|}
\hline & NBR & 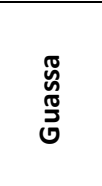 & $\frac{0}{\frac{1}{T}}$ & 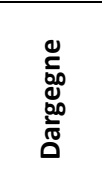 & 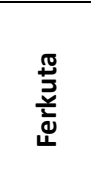 & $\begin{array}{l}\text { 을 } \\
\text { d } \\
\text { d } \\
\mathbb{d}\end{array}$ & 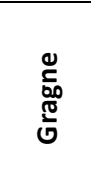 & 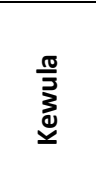 & $\begin{array}{l}\frac{\pi}{d} \\
\frac{d}{0} \\
\frac{d}{3} \\
\frac{1}{3}\end{array}$ & 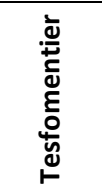 & ī \\
\hline \multirow{5}{*}{ 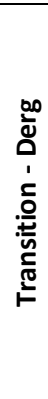 } & $\begin{array}{c}\text { High } \\
\text { Increase }\end{array}$ & $1.5 \%$ & $0.1 \%$ & $0.1 \%$ & $0.1 \%$ & $0.0 \%$ & $0.3 \%$ & $0.2 \%$ & $0.1 \%$ & $0.0 \%$ & $0.4 \%$ \\
\hline & $\begin{array}{c}\text { Low } \\
\text { Increase }\end{array}$ & $29.0 \%$ & $3.2 \%$ & $7.0 \%$ & $3.8 \%$ & $6.1 \%$ & $7.2 \%$ & $10.4 \%$ & $11.1 \%$ & $3.8 \%$ & $14.4 \%$ \\
\hline & $\begin{array}{c}\text { No } \\
\text { Change }\end{array}$ & $68.9 \%$ & $95.8 \%$ & $91.1 \%$ & $92.1 \%$ & $93.8 \%$ & $91.3 \%$ & $87.7 \%$ & $88.2 \%$ & $95.0 \%$ & $75.5 \%$ \\
\hline & $\begin{array}{c}\text { Low } \\
\text { Decrease }\end{array}$ & $0.7 \%$ & $1.0 \%$ & $1.8 \%$ & $4.1 \%$ & $0.0 \%$ & $1.2 \%$ & $1.7 \%$ & $0.6 \%$ & $1.2 \%$ & $9.3 \%$ \\
\hline & $\begin{array}{c}\text { High } \\
\text { Decrease }\end{array}$ & $0.0 \%$ & $0.0 \%$ & $0.0 \%$ & $0.0 \%$ & $0.0 \%$ & $0.0 \%$ & $0.0 \%$ & $0.0 \%$ & $0.0 \%$ & $0.4 \%$ \\
\hline \multirow{5}{*}{ 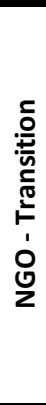 } & $\begin{array}{c}\text { High } \\
\text { Increase }\end{array}$ & $0.1 \%$ & $0.0 \%$ & $0.1 \%$ & $0.2 \%$ & $0.0 \%$ & $0.1 \%$ & $0.2 \%$ & $0.0 \%$ & $0.1 \%$ & $0.0 \%$ \\
\hline & $\begin{array}{c}\text { Low } \\
\text { Increase }\end{array}$ & $4.7 \%$ & $1.0 \%$ & $0.8 \%$ & $2.9 \%$ & $1.6 \%$ & $1.3 \%$ & $2.0 \%$ & $1.0 \%$ & $1.6 \%$ & $2.3 \%$ \\
\hline & $\begin{array}{c}\text { No } \\
\text { Change }\end{array}$ & $91.2 \%$ & $96.6 \%$ & $86.4 \%$ & $90.0 \%$ & $95.0 \%$ & $90.5 \%$ & $83.2 \%$ & $92.4 \%$ & $93.6 \%$ & $79.1 \%$ \\
\hline & $\begin{array}{c}\text { Low } \\
\text { Decrease }\end{array}$ & $4.0 \%$ & $2.4 \%$ & $12.5 \%$ & $6.9 \%$ & $3.4 \%$ & $8.0 \%$ & $14.2 \%$ & $6.6 \%$ & $4.8 \%$ & $18.4 \%$ \\
\hline & $\begin{array}{c}\text { High } \\
\text { Decrease }\end{array}$ & $0.0 \%$ & $0.0 \%$ & $0.1 \%$ & $0.0 \%$ & $0.0 \%$ & $0.1 \%$ & $0.4 \%$ & $0.0 \%$ & $0.0 \%$ & $0.2 \%$ \\
\hline \multirow{5}{*}{ 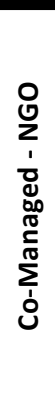 } & $\begin{array}{c}\text { High } \\
\text { Increase }\end{array}$ & $0.1 \%$ & $0.1 \%$ & $0.0 \%$ & $0.1 \%$ & $0.2 \%$ & $0.0 \%$ & $0.0 \%$ & $0.1 \%$ & $0.0 \%$ & $0.1 \%$ \\
\hline & $\begin{array}{c}\text { Low } \\
\text { Increase }\end{array}$ & $1.4 \%$ & $2.1 \%$ & $1.5 \%$ & $2.2 \%$ & $4.0 \%$ & $2.7 \%$ & $2.1 \%$ & $1.0 \%$ & $2.4 \%$ & $4.0 \%$ \\
\hline & $\begin{array}{c}\text { No } \\
\text { Change }\end{array}$ & $76.8 \%$ & $97.5 \%$ & $95.8 \%$ & $94.2 \%$ & $95.6 \%$ & $95.4 \%$ & $93.3 \%$ & $92.1 \%$ & $95.8 \%$ & $90.1 \%$ \\
\hline & $\begin{array}{c}\text { Low } \\
\text { Decrease }\end{array}$ & $21.8 \%$ & $0.2 \%$ & $2.5 \%$ & $3.4 \%$ & $0.2 \%$ & $1.9 \%$ & $4.5 \%$ & $6.8 \%$ & $1.8 \%$ & $5.7 \%$ \\
\hline & $\begin{array}{c}\text { High } \\
\text { Decrease }\end{array}$ & $0.0 \%$ & $0.0 \%$ & $0.2 \%$ & $0.0 \%$ & $0.0 \%$ & $0.0 \%$ & $0.1 \%$ & $0.0 \%$ & $0.0 \%$ & $0.0 \%$ \\
\hline
\end{tabular}

Table A1.4. The percent of land area and direction of vegetation change (from NBR values) for each kebele and the Guassa area across each period of political and management history (dry season). 


\begin{tabular}{|c|c|c|c|c|c|c|c|c|c|c|}
\hline Variable & Water & $\begin{array}{c}\text { Plantation } \\
\text { Forest }\end{array}$ & $\begin{array}{c}\text { Grazing } \\
\text { Land }\end{array}$ & Farmland & Stone & $\begin{array}{l}\text { Bare } \\
\text { Land }\end{array}$ & $\begin{array}{c}\text { Shrublan } \\
\text { d }\end{array}$ & $\begin{array}{l}\text { Native } \\
\text { Forest }\end{array}$ & Guassa & $\begin{array}{c}\text { Mean } \\
\text { Decrease } \\
\text { Accuracy }\end{array}$ \\
\hline elevation & 8.5 & 55.2 & 42.2 & 65.5 & 36.0 & 45.6 & 52.1 & 64.2 & 138.5 & 158.7 \\
\hline CoMgmt_DOY253 & 12.5 & 43.6 & 53.4 & 61.4 & 134.9 & 38.4 & 34.9 & 25.5 & 52.3 & 130.8 \\
\hline Derg_DOY40 & 8.6 & 61.2 & 38.1 & 54.6 & 39.9 & 30.4 & 61.2 & 90.2 & 44.8 & 110.7 \\
\hline greenness & 17.2 & 59.3 & 47.9 & 86.2 & 75.3 & 30.4 & 53.6 & 14.0 & 72.8 & 106.4 \\
\hline Band 4 & 21.6 & 49.6 & 46.8 & 56.5 & 53.9 & 90.4 & 78.5 & 64.3 & 69.5 & 94.5 \\
\hline Band 3 & 21.7 & 49.5 & 40.8 & 56.4 & 31.8 & 87.8 & 40.5 & 31.5 & 59.9 & 88.3 \\
\hline slope & 8.8 & 26.3 & 44.4 & 47.6 & 28.5 & 15.2 & 67.1 & 28.8 & 29.3 & 87.9 \\
\hline Band 5 & 14.5 & 28.3 & 54.9 & 56.5 & 61.9 & 43.6 & 37.9 & 17.2 & 43.6 & 87.0 \\
\hline CoMgmt_DOY40 & 19.4 & 66.5 & 36.5 & 73.9 & 61.0 & 37.0 & 50.2 & 59.0 & 58.2 & 85.3 \\
\hline NGO_Trans_DOY253 & -4.1 & 34.2 & 20.3 & 53.2 & 44.8 & 13.8 & 32.5 & 37.7 & 38.9 & 84.6 \\
\hline NGO_Trans_DOY40 & -0.5 & 63.1 & 13.2 & 24.2 & 33.6 & 29.2 & 21.5 & 27.6 & 24.3 & 83.4 \\
\hline Band 6 & 12.9 & 44.4 & 64.9 & 53.3 & 42.6 & 32.1 & 50.4 & 37.6 & 60.3 & 83.2 \\
\hline NGO_DOY253 & 5.9 & 31.8 & 43.3 & 24.4 & 61.0 & 35.8 & 25.9 & 15.8 & 44.2 & 83.1 \\
\hline Trans_Derg_DOY40 & 2.2 & 58.4 & 12.9 & 17.2 & 37.6 & 15.3 & 22.1 & 45.9 & 25.1 & 83.0 \\
\hline Derg_DOY253 & 10.9 & 51.3 & 39.5 & 19.9 & 44.2 & 29.2 & 44.8 & 33.8 & 48.7 & 82.4 \\
\hline Transition_DOY253 & 4.5 & 34.7 & 48.9 & 31.8 & 52.6 & 24.5 & 25.8 & 15.0 & 54.1 & 80.1 \\
\hline Transition_DOY40 & 2.9 & 37.2 & 33.8 & 48.9 & 33.8 & 23.0 & 38.1 & 53.0 & 41.9 & 80.1 \\
\hline CoMgmt_NGO_DOY253 & 13.7 & 37.9 & 16.8 & 29.7 & 56.8 & 10.3 & 23.7 & 33.8 & 21.1 & 77.3 \\
\hline CoMgmt_NGO_DOY40 & 16.0 & 55.2 & 15.8 & 17.6 & 27.2 & 26.0 & 12.0 & 16.7 & 38.2 & 75.9 \\
\hline Trans_Derg_DOY253 & -1.0 & 50.8 & 21.0 & 5.8 & 29.4 & 8.1 & 28.1 & 43.6 & 26.3 & 72.2 \\
\hline NGO_DOY40 & 6.3 & 43.6 & 30.0 & 48.8 & 38.2 & 29.4 & 34.0 & 58.6 & 36.4 & 72.0 \\
\hline Band 2 & 16.4 & 40.5 & 41.5 & 46.8 & 39.7 & 56.6 & 43.2 & 34.1 & 52.3 & 63.9 \\
\hline wetness & 14.8 & 38.5 & 30.7 & 26.8 & 26.7 & 18.1 & 35.2 & 33.8 & 36.6 & 62.5 \\
\hline brightness & 9.7 & 28.1 & 42.9 & 36.0 & 28.5 & 36.1 & 33.3 & 26.5 & 37.3 & 61.7 \\
\hline Band 1 & 12.5 & 33.9 & 27.0 & 36.8 & 22.7 & 45.3 & 26.9 & 24.0 & 43.1 & 56.1 \\
\hline Band 7 & 15.0 & 38.1 & 40.2 & 32.0 & 26.1 & 36.4 & 35.3 & 38.4 & 38.2 & 55.1 \\
\hline aspect & -2.4 & -1.7 & 6.0 & 4.1 & 1.5 & 9.0 & 13.1 & 7.9 & 14.1 & 20.1 \\
\hline
\end{tabular}

Table A1.5. Relative variable importance (calculated by mean decrease in accuracy) for each predictor variable. Variables are presented in mean decreasing importance across all land classes. 


\begin{tabular}{|c|c|c|c|c|c|c|c|c|c|}
\hline Dry Season & Bare Land & Farmland & $\begin{array}{c}\text { Grazing } \\
\text { Land }\end{array}$ & $\begin{array}{c}\text { Native } \\
\text { Forest }\end{array}$ & $\begin{array}{c}\text { Plantation } \\
\text { Forest }\end{array}$ & $\begin{array}{c}\text { Protected } \\
\text { Grassland }\end{array}$ & Shrubland & Stone & Water \\
\hline Chare & 0.0 & 0.0 & 0.0 & & 0.2 & 0.0 & 0.0 & 0.0 & 0.4 \\
\hline Dergagne & 0.0 & 0.0 & 0.0 & 0.0 & 0.2 & 0.0 & 0.0 & 0.0 & 0.0 \\
\hline Ferkuta & 0.0 & 0.0 & 0.0 & 0.1 & 0.2 & 0.0 & 0.0 & 0.0 \\
\hline Gedenbo & 0.0 & 0.0 & 0.0 & 0.0 & 0.2 & 0.0 & 0.0 & 0.0 \\
\hline Gragne & 0.0 & 0.0 & 0.0 & -0.1 & 0.2 & 0.0 & 0.0 & 0.0 \\
\hline Guassa & 0.0 & 0.0 & 0.0 & 0.0 & 0.3 & 0.0 & 0.0 & 0.0 & 0.0 \\
\hline Kewula & 0.0 & 0.0 & 0.0 & -0.1 & 0.2 & 0.0 & 0.0 & 0.0 \\
\hline Kuledeha & 0.0 & 0.0 & 0.0 & 0.0 & 0.2 & 0.0 & 0.0 & 0.0 & 0.0 \\
\hline Tesfomentier & 0.0 & 0.0 & 0.0 & -0.1 & 0.1 & 0.0 & 0.0 & 0.0 \\
\hline Yedi & 0.0 & 0.0 & 0.0 & 0.0 & 0.2 & 0.0 & 0.0 & 0.0 \\
\hline
\end{tabular}

\begin{tabular}{|c|c|c|c|c|c|c|c|c|c|}
\hline Wet Season & Bare Land & Farmland & $\begin{array}{c}\text { Grazing } \\
\text { Land }\end{array}$ & $\begin{array}{c}\text { Native } \\
\text { Forest }\end{array}$ & $\begin{array}{c}\text { Plantation } \\
\text { Forest }\end{array}$ & $\begin{array}{c}\text { Protected } \\
\text { Grassland }\end{array}$ & Shrubland & Stone & Water \\
\hline Chare & 0.0 & 0.1 & 0.0 & & 0.1 & 0.0 & 0.0 & 0.0 & 0.2 \\
\hline Dergagne & 0.0 & 0.0 & 0.0 & 0.0 & 0.1 & 0.0 & 0.0 & 0.0 & 0.0 \\
\hline Ferkuta & 0.0 & 0.1 & 0.0 & 0.0 & 0.1 & 0.0 & 0.0 & 0.0 \\
\hline Gedenbo & 0.0 & 0.1 & 0.1 & 0.1 & 0.1 & 0.1 & 0.0 & 0.0 \\
\hline Gragne & 0.1 & 0.1 & 0.0 & 0.0 & 0.1 & 0.0 & 0.0 & 0.0 \\
\hline Guassa & 0.0 & 0.0 & 0.0 & 0.0 & 0.1 & 0.0 & 0.0 & 0.0 & 0.0 \\
\hline Kewula & 0.0 & 0.1 & 0.0 & 0.0 & 0.1 & 0.0 & 0.0 & 0.0 \\
\hline Kuledeha & 0.0 & 0.1 & 0.0 & 0.0 & 0.1 & 0.0 & 0.0 & 0.0 & 0.0 \\
\hline Tesfomentier & 0.0 & 0.1 & 0.0 & 0.0 & 0.1 & 0.0 & 0.0 & 0.0 \\
\hline Yedi & 0.0 & 0.0 & 0.0 & 0.0 & 0.1 & 0.0 & 0.0 & 0.0 \\
\hline
\end{tabular}

Table A1.6. Mean NBR change values from Derg to the Co-management period, by land class. 